\title{
"Melting Pot" or "Ring of Fire"?: Assimilation and the Mexican-American Experience
}

\author{
Kevin R. Johnson $\dagger$
}

TABLE OF CONTENTS

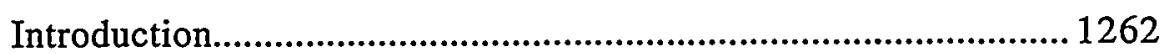

I. The Myth of Spain and Assimilation Through Denial..................1269

II. Race, Ethnicity, and Nationhood for Latinos: Some Assimilation

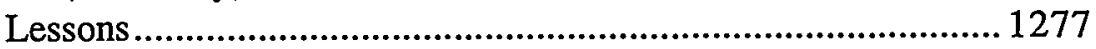

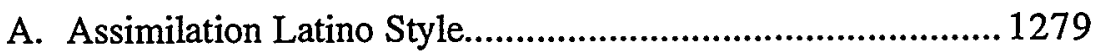

1. Latinos Assimilate! ............................................................ 1281

2. Limits on Latino Assimilation ..........................................1281

a. A Diversity of Assimilation Experiences..................1283

b. Complications of the Border ...................................... 1285

c. The Intersection of Assimilation, Identity Choice, Latino Diversity, and Anglo/Latino Belonging........ 1286

B. Deciding to Be Latino?.......................................................... 1286

C. Latino Diversity ................................................................ 1290

Copyright $(1997$ California Law Review, Inc.

$\dagger$ Profcssor of Law, University of California at Davis. A.B., 1980, University of California at Berkeley; J.D., 1983, Harvard University. This Article is part of a larger project tentatively entitled LifE IN THE Borderlands: A WhITE BROWN MAN'S SEARCh FOR IDENTITY (forthcoming 1998). Arturo Gandára, Edwin Carlos Rocabado, Sylvia Lazos, Joel Dobris, Eliot Dobris, Keith Aoki, Leslie Espinoza, Bob Chang, Margaret Montoya, and Marty West commented on a draft of this Article. Arturo Gandára, Richard Delgado, Christopher David Ruiz Cameron, George Martínez, Bill Piatt, Niko Pfund, and Yxta Maya Murray provided helpful comments on parts of this Article presented in a different form. 1 am appreciative of their comments and support. This Article was presented at the National Association of Chicana and Chicano Studies Rocky Mountain Regional Conference at Arizona State University in January 1997. Thanks to the participants, especially Louis Martinez, Charles Calleros, and Mary Romero, for their comments and encouragement. 1 recounted a number of incidents described in this Article at the first annual Lat/Crit conference in La Jolla, California in May 1996. I thank the conference participants, particularly Frank Valdes, Laura Padilla, Gloria Sandrino, Berta Hernandez, Lisa Iglesias, Rachel Moran, Cynthia Lee, Mary Coombs, Michael Olivias, Jerry Lopez, and Cruz Reynoso, for their support. Melissa Corral, Christine Shen, and Jennifer Shih provided excellent research assistance. 
1. Physical Appearance................................................ 1291

2. National Origin....................................................... 1293

3. Language......................................................... 1294

4. Surnames................................................................. 1295

5. Assimilation Consequences of Latino Diversity ............. 1297

a. Efforts at Social Change: Political Assimilation ...... 1297

b. Affirmative Action and Economic Assimilation...... 1298

D. Where Do Anglo/Latinos Belong?.................................... 1300

1. The Generic Mixed-Race "Problem"......................... 1300

2. Identity Ambiguity for Anglo/Latinos.......................... 1304

3. One Identity Choice..................................................... 1309

Conclusion............................................................................ 1312 


\title{
"Melting Pot" or "Ring of Fire"?: Assimilation and the Mexican-American Experience
}

\author{
Kevin R. Johnson
}

The current movement to restrict immigration to the United States is premised on the notion that today's immigrants refuse to assimilate, unlike previous groups of immigrants. By so doing, these immigrants run afoul of the "Melting Pot" mythology of assimilation. This Article posits that the assimilation paradigm fails to encompass the true assimilation difficulties faced by Mexican immigrants and persons of MexicanAmerican ancestry. Drawing on his and his family's experiences, Professor Johnson analyzes the limits on assimilation for racial minorities in U.S. society. The complexities of the assimilation process are lost in public discourse on the topic. Even if a Mexican-American seeks to assimilate into the mainstream, the costs-which may be quite highoften outweigh the benefits. He or she must carefully navigate through $a$ "ring of fire" in adjusting to life in the United States. Typically barriers such as phenotype (physical appearance), language, and surnames make assimilation extremely difficult. The diversity with respects to these characteristics within the Latino community results in a spectrum of assimilation potentials among the Latino population. Moreover, Latinos who can overcome the barriers and assimilate may internalize racism that elevates the status of Whiteness. At the same time, they expose themselves to criticism from both Anglos and their own community. These contradictions are acute for those of mixed heritage; Professor Johnson points to his own experiences in facing scrutiny from Anglos and Latinos for his own identity choice. In analyzing these experiences, he posits that the increasing number of people of mixed heritages will blur the traditional lines of demarcation between the races. Consequently, the complexities of racial mixture must be addressed in the analysis of race relations in the modern United States. 


\author{
I fell into a burning ring of fire, \\ I went down, down, down \\ the flames climbed higher, \\ and it burned, burned, burned, \\ the ring of fire. ${ }^{1}$
}

\title{
INTRODUCTION
}

In the spring of 1996, I was sitting in a bar close to Pacific Coast Highway in Manhattan Beach, California, an upper middle-class, White suburb of Los Angeles. Funeral services for my father's uncle, my great-uncle (known as "Brown-eyes" or "Brownie" to distinguish him from his blue-eyed twin), had just ended. I had an hour to burn with my father and step-brother while I waited for my return flight to Sacramento. Thoughts about my uncle streamed through my mind. He thoroughly enjoyed life. He was always upbeat. But he worried. A life of economic insecurity for him and his family no doubt contributed to the worries. Over the coming days, I wondered how it must have been when he became the first Anglo in his family to marry a MexicanAmerican woman, Rosie. They had grown up together in a workingclass neighborhood near downtown Los Angeles where MexicanAmericans and Anglos lived side-by-side. They spent fifty years there before moving to the desert to retire.

While my mind wandered, a tall fellow sitting on the barstool next to us talked. He rambled to anyone who would listen about a recent trip to Texas. ${ }^{2}$ Fashioning himself as somewhat of a jokester, he told a series of increasingly bad jokes. Then came what, in retrospect, was inevitable. ${ }^{3}$ For whatever reason, I tuned in to one particular joke, which went something like this: "How do you make sure nobody steals the stereo speakers in your car?" Without waiting for a response, he eagerly offered the pnnch line: "You put a sigu on them saying "no habla español." "Nobody laughed. I wondered why I had to hear this junk.

1. June Carter \& Merle Kilgore, Ring of Fire, on Johnny Cash, The Best of Johnny Cash (Columbia Records 1963).

2. It is somewhat ironic that he recently had visited Texas, "long considered [Chicanos"] Mississippi." Michael A. Olivas, Torching Zozobra: The Problem with Linda Chavez, 2 RECONSTRUCTION 48, 50 (1993).

3. I say "inevitable" because jokes like this one often are made in informal situations. See Richard Delgado, Alternative Dispute Resolution Conflict as Pathology: An Essay For Trina Grillo, 81 MinN. L. REv. 1391, 1398 (1997). 
Why couldn't I grieve over a beer and not have to deal with some buffoon making jokes that instantIy cut to the core of my identity? I was too tired from the travails of the funeral day-with grieving family, sad combined with happy remembrances, and thoughts of my own mortality-to care, much less lash back at the happy-go-lucky Texan. Shaking my head, I stared blankly at my beer. "Can I have another?," I asked the bartender as I emptied my glass. ${ }^{4}$

The Texan got me thinking. On the flight from Los Angeles to Sacramento, I wondered what it would be like for my identity to be "transparent," a non-issue in my daily life, like it is for many, if not most, whites. ${ }^{5}$ His joke also made me think of the many Spanishspeakers who I knew and my inability to identify any who stole stereo speakers. This story shows how a few words may hurt and marginalize. ${ }^{6}$ It also, I thought, demonstrates the limits of assimilation for Latinos, even those who are half White and look the part.

$$
\text { ***** }
$$

In light of the duality of my identity, ${ }^{7}$ it is entirely appropriate to begin this article about Latino identity with lyrics to a song popularized by a country and western singer. I was born in 1958 at the tail end of the so-called Baby Boom. I identify as a Latino, ${ }^{8}$ specifically a

4. This type of experience is not uncommon for racial minorities who "look" White. See, e.g., Judy Scales-Trent, Notes of a White Black Woman 13 (1995) (telling of incident in which cabdriver made racist comment in her presence and observing that she is alert to such comments calling her identity into question); see also Mary Coombs, Interrogating Identities, 11 BERKELEY WOMEN's L.J. 222, 240 n.97, 2 AFRICAN-AM. L \& POL'Y REP. 222, 240 n.97 (1996) (published concurrently) (noting that "I find myself in the position to hear anti-Semitic remarks and jokes more easily because my name allows me to pass unless and until I consciously and explicitly "come out."').

5. See Barbara J. Flagg, "Was Blind, But Now I See": White Race Consciousness and the Requirement of Discriminatory Intent, 91 MicH. L REv. 953, 957-58 (1993) (analyzing "transparency" of Whiteness).

6. See Richard Delgado, Words That Wound: A Tort Action for Racial Insults, Epithets, and Name-Calling, I7 HARv. C.R.-C. L. REv. 133, 143-49 (1982) (analyzing harms of racial insults); Mari J. Matsuda, Public Response to Racist Speech: Considering the Victim's Story, 87 MicH. L. REv. $2320,2335-41$ (1989) (analyzing negative effects of racist hate speech).

7. This duality is not without costs. See Everetr V. Stonequist, The Marginal MaN at xv (1937) (studying "the marginal man, ... one whom fate has condemned to live in two societies and in two, not merely different but antagonistic, cultures"); $c f$. W.E.B. Du BoIs, THE Souls OF BLACK Folk 5 (Penguin Books ed. 1989) (noting the "double consciousness" of African-Americans and the feeling of "twoness-an American, a Negro; two souls, two thoughts, two unreconciled strivings; two warring ideals in one dark body, whose dogged strength alone keeps it from being torn asunder").

8. I prefer the term Latino over "Hispanic," a term coined by the U.S. government for census purposes. See Suzanne Oboler, Ethnic Labels, Latino Lives: Identity and the Politics of (Re)Presentation in the United States 1 (1995) (quoting Population Division, U.S. Bureau of the Census, Development of the RaCe and Ethic Items for the I990 Census 51); see generally OBOLER, supra (analyzing various difficulties in construction of Latino identities); Angel $R$. Oquendo, Re-Imagining the Latino/a Race, I2 HaRv. BlackLETTER J. 93, 96-99 (1995) (discussing 
Mexican-American or Chicano. My mother, a first- or secondgeneration Mexican-American (her maiden name was Angela, or as she prefers to be called Angie, Gallardo), was born a few miles north of the U.S.-Mexico border in Brawley, a small farm town in the Imperial Valley of California. My father (Kenneth Johnson) is an Anglo who grew up in what was then a mixed Mexican/Anglo working-class neighborhood near Chavez Ravine, today the site where the Los Angeles Dodgers play baseball.

To analyze some difficult but crucially important issues for Latinos in the United States today, I plan to borrow from my mother's experiences. Though aware of the alleged deficiencies of the use of autobiography in legal scholarship, ${ }^{9}$ I write this hoping to bring to the fore the stories of some Latinos who have been invisible or ignored, and to offer more general insights based on those experiences. ${ }^{10} \mathrm{My}$ firm conviction is "that Mexican Americans need to tell their side of the story ...." I am part of that story.

Specifically, this Article explores the assimilation of Latinos into dominant society, with a focus on the experience of Mexican-Americans in the Southwest. In recent years, Latino intellectuals frequently in the

terminology). I use Latino solely for sake of simplicity, without meaning to marginalize Latinas in the community in any way.

9. For a critical view of autobiography in outsider legal scholarship, see Anne M. Coughlin, Regulating the Self: Autobiographical Performances in Outsider Scholarship, 81 VA. L. REv. 1229 (1995). For responses, see Richard Delgado, Coughlin's Complaint: How to Disparage Outsider Writing, One Year Later, 82 VA. L. Rev. 95 (1996); Jcrome McCristal Culp, Jr., Telling a Black Legal Story: Privilege, Authenticity, "Blunders," and Transformation in Outsider Narratives, 82 VA. L. REv. 69 (1996); Robert L. Hayman, Jr. \& Nancy Levit, The Tales of White Folk: Doctrine, Narrative, and the Reconstruction of Racial Reality, 84 CALIF. L. REv. 377, 400 n.83, 429 n.158 (1996).

Despite the claims that autobiography is used by outside scholars for fame and fortune, see Coughlin, supra, at 1232, 1283-84, my instincts told me that relating these stories would not enhance my career. Nonetheless, 1 thought it important to publish this Article because it raises issues of general importance to the Latino community that have not been discussed in traditional legal scholarship. See Susan Rubin Suleiman, Risking Who ONe Is 214 (1994) ("[T]he only kind of autobiography I find truly essential, to read or write... is the kind that tries to recover, through writing, an irrecoverable absence."); $c f$. Randall L. Kennedy, Racial Critiques of Legal Academia, 102 HARV. L. REv. 1745, 1810-19 (1989) (articulating reasons why Kennedy rejected advice not to publish article, all involving the need for full academic discussion of issues of race).

10. See Kevin R. Johnson, Some Thoughts on the Future of Latino Legal Scholarship, 2 Harv. LATINo L. REV. (forthcoming 1997) (contending that Lat/Crit theory promises to change the fact that Latinos are forgotten in constructive dialog to improve race relations in U.S.); $c f$. Daniel A. Farber \& Suzanna Sherry, Telling Stories Out of School: An Essay on Legal Narratives, 45 STAN. L. REv. 807, 829 n.119 (1993) (noting that storytelling may be particularly useful a way of filling in scholars' informational gaps about lesbians and gays who are "closeted" and about whose lives information may be unavailabie).

11. MARY Helen PONCE, Hoyt Street at x (1993) (prefacing autobiography of MexicanAmerican from Southem Califomia). 
media spotlight, such as Linda Chavez ${ }^{12}$ and Richard Rodriguez, ${ }^{13}$ have unabashedly embraced assimilation for Latinos. In her book, Chavez explores a "new theory" of assimilation that argues that Latinos, like previous waves of White "ethnic" immigrants, should, and in fact are, assimilating. The validity of this hypothesis is far from self-evident. Separate and unequal Latino enclaves in many cities suggest that assimilation is far from complete. Economic disparities exist and show no signs of dissipating. ${ }^{14}$ The anti-immigrant backlash, which is in no small part an attack on all persons-citizens as well as immigrants-of Mexican ancestry in the United States, including persons who can trace their ancestry in this country for centuries, is testament to the limits of Latino assimilation. ${ }^{15}$

On a human level, the experiences of my grandmother and mother, two of the most ardent Mexican-American assimilationists that one could ever want to meet, demonstrate the problems faced by Latinas seeking to assimilate. They never succeeded and suffered immensely for their efforts. Nor, however it may appear to the world, am I, a Harvard-educated law professor, fully assimilated into the mainstream. $^{16}$

Latino assimilation implicates issues central to race, ethnicity, and nationhood. A growing body of academic literature ${ }^{17}$ analyzes generally the voluntary adoption of a racial identity. My experiences exemplify how, because race is a social construction, people-at least somedecide to be Latino. For the most part, I was never forced to present

12. See Linda Chávez, OUt of the Barrio (1991).

13. See Richard Rodríguez, Hunger of MEMory (1981).

14. See Carey Goldberg, Hispanic Households Struggle Amid Broad Decline in Income, N.Y. Trmes, Jan. 30, 1997, at A1 (reviewing Bureau of Census data showing that poverty rate among Hispanics in U.S. had surpassed that of Blacks and that Hispanics constituted almost one-fourth of all poor in the nation).

15. See Kevin R. Johnson, An Essay on Immigration Politics, Popular Democracy, and California's Proposition 187: The Political Relevance and Legal Irrelevance of Race, 70 WASH. L Rev. 629, 650-58 (1995) (analyzing anti-Mexican, not just anti-“illegal alien," element to Proposition 187 campaign).

16. Leslie Espinoza has captured the self-doubt experienced by a minority who is successful by traditional standards. See Leslie G. Espinoza, Masks and Other Disguises: Exposing Legal Academia, 103 HARV. L. REv. 1878, 1884 (1990) ("[M]y life is so surprising to me, so unexpected. It makes two things easier to believe: there are very few others like me, and because there are so few, my success must be a mistake, an aberration."). Such doubt reveals the difficulties of assimiliating faced by the most successful Latinos. See infra text accompanying notes 63-100.

17. See, e.g., David A. Hollinger, Postethnic America (1995); Mary C. Waters, Ethnic Options (1990); see also Karen J. Winkler, Scholars Explore the Blurred Lines of Race, Gender, and Ethnicity, CHRON. HrGHER EDuc., July 11, 1997, at All (describing burgeoning scholarship on persons crossing boundaries of race, gender, and ethnicity). 
myself as Mexican-American. Although it may be difficult for some Latinos to "pass" as White due to phenotype, surname, language skills, or accent, I could, if I chose. I might have ignored my background and hoped that uobody would remember, find out, or care, although to do so, I would have had to deny a family history that grew increasingly central to my identity over my lifetime. Exemplifying the volitional nature of racial identity, my brother, with sandy blond hair and blue eyes, exercised his right to choose in a different way. He never identified as Mexican-American.

Because the community is extremely diverse, the ability to choose an identity and assimilate differs among Latinos. ${ }^{18}$ My family history exemplifies Latino heterogeneity. While many might hail multiculturalism and revel in the mix of different cultures in the United States, I am multicultural. ${ }^{19}$ I share dark brown hair and brown eyes with my mother but also bear the last name Johnson and the height of my father's side of the family. My brother's blond hair and blue eyes more closely resemble my father's family, though he is short in stature like my mother's side. My mother speaks some Spanish but never taught the language to her sons.

My wife, Virginia Salazar, is from a traditional Mexican-American family in La Puente, California, east of East Los Angeles, with dark brown hair and brown eyes and a light complexion. Those in her mother's family generally have fair complexions and light brown hair; those in her father's family generally have dark skin and dark brown hair bordering on Black. Although both her parents speak Spanish, she was not taught the language at home. To our surprise, our first two children, Teresa and Tomás, have blond hair and blue eyes and fair complexions. They at times have been referred to as "güeros," (Spanish slang for "White ones"). ${ }^{20}$ Such references hint at the value of Whiteness in U.S. society. Our third child, Maria Elena, looks more like us, with olive colored skin, dark brown hair, and brown eyes. Some have referred to her as our "Mexican" baby or "la morena" (the dark one). ${ }^{21}$

18. See infra text accompanying notes 122-169 (analyzing implications of Latino diversity).

19. See Philip Tajitsu Nash, Multicultural Identity and the Death of Stereotypes, in Racially Mixed People in America 330 (Maria P.P. Root ed., 1992) ("Those of us with parents of two distinct 'racial' backgrounds are a visible reminder that everyone is multicultural and deserves to be treated as a multifaceted individual." (emphasis in original)).

20. For experiences of a mixed White/Mexican-American who is a self-proclaimed "güera," see Cherrí Moraga, Loving in the War Years 50-59 (1993).

21. As this suggests, skin color is one way that many persons categorize others. See BILL Piatt, Black aNd Brown in America 158 (1997) (recounting story of President George Bush 
The phenotypic diversity among a family of five MexicanAmericans under one roof should make it clear that the MexicanAmerican community is far from one-dimensional. If MexicanAmericans are a diverse group, Latinos are even more so. Mixtures of race, national origin, immigration status, class, culture, education, political outlook, and many other characteristics abound.

One aspect of Latino diversity is the existence of persons of mixed Latino/Anglo backgrounds. ${ }^{22}$ While poignant books by Greg Williams, ${ }^{23}$ Judy Scales-Trent, ${ }^{24}$ and others have documented the experiences of persons with one Black and one White parent, the discussion of mixedrace people has not focused on Latinos of mixed parentage. This is true despite the high rates of intermarriage between Latinos and Anglos and the many mixed Latino/Anglo people in the United States. ${ }^{25}$ As the Latino population in the United States increases, one can expect the number of intermarriages and mixed-race children to increase as well.

Changing demographics require careful examination of the breadth of the Latino experience in the United States. According to projections, by 2005 , Latinos will be the largest minority group in the United States. ${ }^{26}$ If current demographic trends continue, by the middle of the twenty-first century, persons of mixed-race backgrounds will increase greatly as a proportion of the U.S. population. ${ }^{27}$ With the changing demographics, race relations and individual experiences will change. Legal analysis of issues of race in this country must change as well.

Some of my experiences exemplify the difficulties of forcing people into hard-and-fast categories, which law and society inevitably

referring to his grandchildren, who have a Latina mother, as "little Brown ones"); see also infra text accompanying notes 127-134 (discussing variety of phenotypes found among Latinos).

22. For a general discussion of the increasing numbers of mixed-race people in the United States, see Gabrielle Sándor, The "Other" Americans, AM. Demographics, June 1994, at 36.

23. See Gregory Howard Williams, Life on the Color Line (1995).

24. See SCALES-Trent, supra note 4.

25. See infra text accompanying notes 190-232 (discussing identity issues for mixed Anglo/Latinos).

26. See Katharine Q. Seelye, U.S. of Future: Grayer and More Hispanic, N.Y. Tmmes, Mar. 27, 1997, at B 16 (reporting that Bureau of the Census report projected that, because of immigration combined with high fertility rates, Latinos by year 2005 will surpass African-Americans as largest minority group in U.S. and will constitute about one-fourth of the total U.S. population in 2050).

27. See 62 Fed. Reg. 36,874, 36,901 (July 9, 1997) (summarizing data on increasing rate of interracial marriages and children over tail end of twentieth century). 
attempt to do. ${ }^{28}$ Mixed-race people regularly face this difficulty. For example, in the United States census, what demographic box should a person check who does not fit neatly into any of the enumerated racial or ethnic categories? The example holds true for admission to educational programs and for employment. None of the recognized categories fully nor accurately describe a mixed-race/ethnicity person. One hates to be in the unsavory position of denying one's background. At the same time, one fears being accused of claiming to be a minoritysometimes by inembers of the very group with which he or she identifies-simply to obtain a "special" preference. ${ }^{29}$

Ultimately, the assimilation experiences of Latinos reveal much about race, ethnicity, and nationhood in the United States. This explains why Latino scholars have begun focusing attention on the limits of Latino assimilation. Mexican-Americans in the Southwest, and Latinos throughout the country, have been defined as a race of people different from and inferior to Whites. Latinos are viewed as foreign to the Anglo-Saxon core of the United States and thus as "foreigners" to the nation..$^{30}$ Difficulties of assimilation for Latinos persist in part because of their definition as the Other. The stories of my mother and grandmother reflect the difficulties of assimilation for Latinas. Moreover, they serve as sad inetaphors for the story of the assimilation of

28. See Peggy C. Davis, Law as Microaggression, 98 YALE L.J. 1559, 1561-62 (1989) (analyzing human need to categorize in context of race relations); Charles R. Lawrence 1II, The Id, the Ego, and Equal Protection: Reckoning With Unconscious Racism, 39 STAN. L. Rev. 317, 336-39 (1987) (analyzing psychological phenomenon of "categorization" in development of racial stereotypes); see also Linda Hamilton Krieger, The Content of Our Categories: A Cognitive Bias Approach to Discrimination and Equal Employment Opportunity, 47 STAN. L. Rev. 1161 (I995) (contending that much modern racial discrimination can be explained by cognitive thcory and unintentional categorization error); $c f$. John D. Ayer, Isn't There Enough Reality to Go Around? An Essay on the Unspoken Promises of Our Law, 53 N.Y.U. L. REv. 475 (1978) (analyzing generally the failure of law to consider the complex realities of human existence). For an analysis of costs and benefits that categories may have on self-identity, see RUTH ColKer, HYBRID: Bisexuals, Multiracials, ANd Other Misfits UNDER American Law I5-38 (1996).

29. In recognizing Latino diversity, I do not mean to in any way question affirmative action. See infra note 118 and accompanying text (describing generally affirmative action). Though far from perfect, affirmative action serves many important functions. See generally Paul Brest \& Miranda Oshige, Affirmative Action for Whom?, 47 StaN. L. Rev. 855 (1995) (articulating affirmative action rationales for various minority groups); David Benjamin Oppenheimer, Understanding Affirmative Action, 23 HASTINGs CoNST. LQ. 921 (1996) (arguing for retention of affirmative action); see also infra text accompanying notes 118-119, 162-168 (analyzing complexities of affirmative action in multiracial world).

30. See Johnson, supra note 10. The growing critical Latino theory movcment has focuscd attention on the treatment of Latinos as foreigners. For important foundational readings on this and related subjects, sce The Latino Condition: A Critical Reader (Richard Delgado \& Jean Stefancic eds., forthcoming 1998). 
Mexican-Americans in the Southwest. My experiences reflect the amorphousness of the concept of race, the difficulties resulting from racial uncertainty, and the complexities of racial mixture in a time of identity politics.

The Myth of Spain and Assimilation Through Denial

In the spring of 1996, I was invited to speak at Michigan State University, located in Lansing, Michigan. While in Lansing, I met with a group of community activists. At an informal dinner in a local community center, Cristo Rey, in a part of town where many MexicanAmericans live (like that found in so many others cities across the country), I sat next to a member of the Lansing City Council, a warm, congenial Mexican-American. I almost inmediately felt comfortable with him. We talked politics, family, and other matters. I told him, among other things, that my mother was Mexican-American. After talking for awhile, he stated bluntly that "your mother got your heart." He then told me how his own daughter, who had married an Anglo, made sure that the children were aware of their Mexican-American heritage. His simple observation said volumes about the genesis of my racial identity.

$* * * *$

Approaching sixty years, my mother, born Angela Gallardo, has lived a difficult life. Although nobody would or could ever fill me in on all the details, according to family lore, my grandmother was born in El Paso, Texas, though instincts tell me she was born in Mexico. Her mother, my great-grandmother (Josephine Gonzales), was a Mexican citizen who lived in Mexico most of her life. My mother was born in 1938 in Brawley, California, a small agricultural town in the Imperial Valley, about an hour's drive from San Diego. About all my family told me about my mother's father, my maternal grandfather (Charles Daniel Swalez), is that he was killed in an automobile accident when my mother was a child. A sprinkling of distant family still lives in the Imperial Valley area, though my mother lost touch with them long ago, something not that uncommon for Latinos in rural communities. ${ }^{31}$

My mother grew up in downtown Los Angeles. With olive colored skin and gray hair that once was black (she always emphasized that it

31. For a literary account of the loss of touch with family and the blurring of family lines among Mexican farmworkers, see Helena María Viramontes, Under the Feet of Jesus (1995). 
was "dark brown"), she stands just under five feet tall. In her younger adult years, and intermittently now, she talked incessantly. Her preferred nickname, Angie, reflects the assimilationist tendencies she shared with my grandmother. My mother was a diligent, hard-working student raised Catholic. She was the first in her family to graduate from high school, and then attended Los Angeles City College, where she met my father. Her education was quite an accomplishment for a MexicanAmerican woman in Los Angeles in the 1950s. Every once in a while, though less frequently as she grows older, my mother talks of her dream of becoming a dental technician.

Married in a Catholic ceremony in Los Angeles in 1957, my parents were young newlyweds, my mother just $19 .{ }^{32} \mathrm{I}$ was born almost one year later in Culver City where my father worked for a newspaper. My brother Michael was born almost three years after me. Not long after his birth, my parents separated and eventually divorced. Divorce was not as simple in the 1960s as in the $1990 \mathrm{~s}^{33}$ Theirs was acrimonious, requiring trial separations, numerous court appearances, and findings of fault. This took time and stressed all members of the disintegrating family. After the divorce, my mother moved to Azusa, a suburb east of Los Angeles in the San Gabriel Valley where my maternal grandmother lived. Not to be confused with Los Angeles' San Fernando Valley and its upscale image, the San Gabriel Valley of that era was mostly a bluecollar, racially-mixed area, including working-class Whites and Mexican-Americans. ${ }^{34}$

My mother lived by a strict moral code that was especially rigid for women. ${ }^{35}$ Her strait-laced nature stood in stark contrast to my

32. The duality running through my mother's life is reflected in the guest lists to her four wedding showers recorded in her "Our Wedding Memories" book. Guessing from surnames, the guests at three of the showers were primarily Anglo; another was predominately Mcxican-American.

33. See Herma Hill Kay, Equality and Difference: A Perspective on No-Fault Divorce and lts Aftermath, 56 U.CIN. L REv. 1, 4-14 (1987) (summarizing developinent of no-fault divorce movement and passage of divorce reform legislation in California in 1969).

34. Since I moved away in the 1970 s, the raeial mix of the San Gabriel Valley has changed as a significant number of Asian immigrants have moved there. See RoBERT BACH, NATIONAL BOARD of Changing Relations Project, Changing Relations: Newcomers and Established Residents IN U.S. Communities 15-I6 (I993) (observing demographic changes in Monterey Park, a city in the San Gabriel Valley, as part of a study of conflict between minority groups); see also Robert Chang \& Keith Aoki, Centering the Immigrant in the Inter/National Imagination, 85 CAL.1F. L. REv. 1395, 1417-46 (1997), 10 LA RAzA LJ. 309, 331-60 (1997) (analyzing multiracial political dynamics of Monterey Park).

35. For analysis of the images of mothers in Latin culture, see Elizabeth M. Iglesias, Rape, Race, and Representation: The Power of Discourse, Discourses of Power, and the Reconstruction of Heterosexuality, 49 VAND. L. REv. 868, $915-29$ (1996). 
happy-go-lucky grandmother. Julia, as my grandmother called herself (Hortense was her name by birth), enjoyed life. She told me many a story as I grew up, fantastic tales that were upbeat, funny, and uplifting. ${ }^{36}$ My brother and I looked forward to riding our bikes to her house. She loved her daughters (my mother had two half-sisters), taught me how to make guacamole, and would make me a quesadilla or a hamburger whenever I asked for one, day or night. She made a dish called picadillo (a stew of meat and potatoes), which I crave to this day. In her youth, she had lived in far-away San Francisco, which in my eyes seemed a distant, foreign place. It was unclear what she did there, though the family murmured of some wild life. A picture from that era of her and my mother, as a child, in fur coats "document" that time.

This effervescent side of my grandmother masked a tough life, which necessitated much hard work and moving around from San Francisco to East Los Angeles to Valencia Street in downtown Los Angeles. She never married my mother's father and would never talk about him. My mother would only say that he hurt my grandmother deeply. The story of his death in a car accident may have been more figurative than literal.

After her San Francisco days, my grandmother, still an attractive young woman, married an Anglo (just as her three daughters later did) ${ }^{37}$ Angry and irritable, he psychologically and physically abused her. Growing up, I would visit my grandmother only during the daytime when he was not around. Daytime visits spared me exposure to the verbal and physical assaults that she suffered in the evenings. Although the neighbors must have heard some of the yelling, the battered women of the 1960s had few options. One lasting impression forever sticks in my mind-a bent-up fork flying through the air, hitting the wall, and landing at my feet. I must have been six or seven years old. My

36. Stories play an important role in Mexican-American culture. For stories told by MexicanAmerican grandparents, see Yxta Maya Murray, Merit-Teaching, 23 Hastings ConsT. LQ. 1073 (1996), Michael A. Olivas, The Chronicles, My Grandfather's Stories, and Immigration Law: The Slave Traders Chronicle as Racial History, 34 ST. LouIs U. L.J. 425 (1990); Christopher D. Cameron, Border Views: Immigration Reform Bashes Mexican-Americans, EL PASO TIMES, Apr. 24, 1994, at 26.

37. My mother has two half-sisters, both closer to my age than hers. Neither identifies as Mexican-American, though both share an Anglo father and Mexican-American mother. Both married Anglo men in their teens only to have their first marriages fail. Both ended up re-marrying non-Anglos, one a Mexican-American and the other an American Indian. My seven cousins run the gamut of physical appearances but, to my knowledge, none considers himself or herself to be Mexican-American. 
grandmother's lifeboat was alcohol. Though many in the family were quick to criticize her for drinking, I can understand it.

Despite their Mexican roots, my mother and grandmother were ardently assimilationist in outlook. Marrying Anglo men was part of the grand assimilationist strategy. Another aspect of the plan was for my mother and grandmother to claim that they were not of Mexican, but Spanish, ancestry. Always the storyteller, one of my grandmother's favorite tales concerned her mixed Spanish-French background, with particular emphasis on the Spanish. ${ }^{38}$ This theme, in fact, found itself in many of her stories. My mother also claimed a "Spanish" ancestry. ${ }^{39}$

Over the years, I realized this elusive Spanish heritage was very much an exaggeration. My grandmother, with her indigenous phenotype, and my mother with her olive-colored skin seemed no different from the other Mexican-Americans in the San Gabriel Valley. My great-grandmother, who never mentioned her Spanish background in my presence, was a Mexican citizen who lived in Mexico. All of our relatives in the Imperial Valley, only a few miles from the U.S./Mexico border, were Mexican-American. "Where are all the Spaniards?" I could only wonder.

A "Spanish" heritage is not an uncommon myth and indeed is one embraced by some Latinos today. Many understand at least implicitly that being classified as Mexican is disfavored in the United States, especially in the Southwest before the development of the civil rights consciousness of the $1960 \mathrm{~s}^{40}$ The phenomenon of Latinos attempting to "pass" as Spanish, and therefore as White, is a variation of the "passing" of other minorities as White.41 To many Anglos, being "Spanish" is more European, and therefore more acceptable to Whites,

38. Attempts by Mexican-Americans to "pass" as White are common. See Rodolfo F. ACuÑa, ANything But MExican 8 (1996) (stating that "[s]ome Mexicans, despite their strong indigenous faces, will confide that they have a French grandmother"); CAREY McWILLIAMS, NorTH FROM MEXICO 43-53 (rev, ed. 1990) (analyzing commonplace phenomenon of Mexican-Americans in Southwest claiming "fantasy [Spanish] heritage").

39. The efforts to "pass" as Spanish, as well as a disdain for Mexican immigrants, may reflect identification with the dominant group and self-hate. See Gordon W. Allport, The Nature of Prejudice 150-53 (1979 ed.).

40. That is not to suggest that anti-Mexican sentiment is something of the distant past. See supra note 15 and accompanying text (mentioning Proposition 187 campaign as example). Margaret Montoya, for example, tells of a racial epithet directed at her from the chair of her undergraduate department. See Melissa Harrison \& Margaret E. Montoya, Voices/Voces in the Borderlands: $A$ Colloquy on Re/Constructing Identities in Re/Constructed Legal Spaces, 6 CoLuM. J. GENDER \& L. 387, 403 (1996).

41. See infra text accompanying notes 197-207 (analyzing concept of "passing"). 
than being of Latin-American ancestry. ${ }^{42}$ My mother and grandmother knew the southern Californian world in which they lived and the racial hierarchy that existed, even if they recognized it in simple terms (i.e., that many people did not like Mexicans and that they had better convince them they were not Mexicans).

This Spanish mythology was fully consonant with my mother's assimilationist leanings. ${ }^{43}$ To this day, rather than pronounce her maiden name (Gallardo) in proper Spanish, which requires a special "ll" sound similar to "y," she says it as it would be said in English, as in the word "fallen." Consequently, the word "lard," and all of the images that the word connotes, sticks out right in the middle. My wife Virginia and I laugh about it today. But those efforts served a critical function for my mother and many others of her generation. The Anglicizing, thereby "Whitening" of their Spanish last names, was an important step for a Mexican-American attempting to pass as White.

In no small part because of her assimilationist nature, my mother consciously avoided teaching her children Spanish. ${ }^{44}$ She spoke Spanish, though losing some of it over the years. Like many in her generation, Spanish was considered an educational impediment. The theory was that we needed to master English (which would not be possible if we learned Spanish) so that we could succeed in school, a view held to this day by some Latinos. In my mother's generation, it was not unheard of for public school teachers to punish students for speaking

42. See Julia Alvarez, How the García Girls lost Their Accents 98-99 (1991) (offering a fictional account of an Anglo telling his parents that his Latina friend was "Spanish"); see also AcuÑ A, supra note 38, at 1-2 (mentioning efforts to characterize Mexican food and culture in Los Angeles as "Spanish").

43. Assimilationism of this nature unfortunately fits into a larger pattern among MexicanAmericans in the Southwest: "Latina/o history is replete with stories about those who changed their names, lost the Spanish language.... or deliberately married out of the culture. In short, some did whatever was necessary to be seen as not-different by the majority." Margaret E. Montoya, Mascaras, Trenzas, y Greñas: Un/Masking the Self While Un/Braiding Latina Stories and Legal Discourse, 17 Harv. Women's L.J. 185, 193 (1994), 15 Chicano-Latino L. Rev. 1,9 (1994) (footnote omitted) (published concurrently); see also OsCAR J. MARTínez, Border PeOPLE: Life AND SOCIETY IN THE U.S.-MEXICO BORDERLANDS 93-99 (1994) (describing assimilationists among Mexican-Americans).

44. This experience is common. See Steven W. Bender, Consumer Protection for Latinos: Overcoming Language Fraud and English-Only in the Marketplace, 45 AM. U.L. REv. 1027, 1032 n.17 (1996) (describing a similar experience); Christopher David Ruiz Cameron, How the Garcia Cousins Last Their Accents: Understanding the Language of Title VII Decisions Approving SpeakEnglish-Only Rules as the Product of Racial Dualism, Latino Invisibility, and Legal Indeterminacy, 85 Calif. L. Rev. 1365-66 (1997), 10 La RazA L.J. 279-80 (1997). 
Spanish. ${ }^{45}$ When I was growing up, my mother and grandmother spoke Spanish only when they wanted to have a private conversation in our presence. My mother would become irritable-rare for her-when my brother and I teased her for speaking "Mexican." "It is Spanish," she would emphasize. "There is no Mexican language."

While my mother and grandmother lived in a state of denial, the Anglo men in the family often emphasized their Mexican ancestry, though in dramatically different ways. When my grandmother talked about her Spanish background, my step-grandfather would sarcastically respond: "Get off it. You're a Mexican like the rest of them." Weakly saying that he did not know anything and laughing uncomfortably, my grandmother was visibly wounded. Similar exchanges occurred regularly. In a much more constructive way, my father would emphasize the positive side of my mother's Mexican background to me. He told me as a child that the mixture of his "Swedish," an exaggeration, and my mother's Mexican bloodlines was good and that I would be strong.

My mother's and my grandmother's assimilationism also meant adoption of the dominant society's racial attitudes. From an early age, my grandmother warned me never to bring home an African-American girlfriend. She jokingly would say things to me like "Don't bring home anyone who wants pork chops." We ate pork chops but I knew what she meant. Though she said this with a laugh, I understood her seriousness. Although my mother would never say such things, I sensed her agreement. My mother and grandmother also considered immigrants from Mexico as lessers, referring to them (jokingly, of course) as "wetbacks" or "Julios." Mexican immigrants were consistent with the denial of their Mexican ancestry and efforts to "pass" as Spanish.

My mother never recovered from the break-up of her first marriage. Part of this has to do, I think, with her Catholic upbringing and the moral code that Catholicism imposed on her life. In the Catholic

45. See Montoya, supra note 43, at 189-90; see also Juan F. Perea, Los Olvidados: On the Making of Invisible People, 70 N.Y.U. L. REv. 965, 965 (1995) (noting that Spanish "frightens many Latinos, for it proclaims their identity as Latinos, for all to hear" and "may subject Latinos to the harsh price of difference").

46. As this suggests, one way to assimilate is by adopting dominant society's views about race. For example, Professor Gerald Torres has told about his father who, although personally discriminated against in buying a house, voted in favor of an initiative designed to repeal fair housing laws. See Charles R. Lawrence III, Foreword: Race, Multiculturalism, and the Jurisprudence of Transformation, 47 STAN. L. REV. 819, 834-35 (1995) (recounting story told by Torres at the Society of American Law Teachers' 1995 Robert Cover Memorial Study Group). 
church, it is expected that you marry only once and for life. Many Catholics today understand that this is not how many lives play out. But my mother was Catholic in an old-fashioned way and failed to adjust well to the concept of divorce. Moreover, because her identity was in large part defined by her husband, the divorce disrupted her entire life. ${ }^{47}$

Beginning with the divorce, my mother began suffering from deep depression, later diagnosed as schizophrenia. Listless and nearly speechless, she would sit in a sad, distant trance. This contrasted sharply with her mile-a-minute talking. In some ways, the first divorce began a downward spiral. A pattern emerged of hospitalization followed by heavy medication and temporary improvement.

In the late $1960 \mathrm{~s}$, my mother met another Anglo man, got pregnant, had a baby, and got married, in that order. Years later, she proudly told me that the welfare doctors told her that having the baby would place her life at risk and advised her to have an abortion. On Catholic principle, she steadfastly refused and instead took her chances with childbirth, which fortunately did not take her life.

The second marriage was delayed because her new husband-to-be did not want my brother and me to be a part of his new family. My mother refused to give up her two sons and, eventually, he relented. With a new breadwinner, we were off welfare, and for a few years my brother and I lived with my mother and her new husband. Like my grandmother's Anglo husband, he talked in jest of "spics" and "taco benders," thereby reminding my mother of her Mexican ancestry and her sons of their dubious heritage.

Over the years, my mother's mental condition worsened. ${ }^{48} \mathrm{Her}$ moods swung dramatically from good to bad and back again. Her second husband unceremoniously left her and she returned with my halfbrother to the very same apartment where we had lived before her

47. To make matters worse, the employment market was not the best for a Mexican-American woman. My mother tried hard for several years after the divorce to land a good job. She made daily trips to the unemployment office. Her efforts, often harrowing to my brother and me, to learn to drive so that she could work, refiected hope for a better future. A good job just never came. For a short time, she cleaned houses. Child care responsibilities proved an impediment to this and other employment efforts. My father dutifully paid child support. Nonetheless, my mother's unemployment made it necessary for us to receive welfare, foodstamps, and other public benefits.

48. When I was in junior high school, my father successfully sought custody of his two sons. The custody battle was facilitated by my step-father who contacted my father to suggest to him that my mother was an unfit mother. My brother and I went to live with my father when I was in the seventh grade. Losing two of her sons drove my mother into deeper depression. Medicated and uncommunicative, she was hospitalized. We did not hear from her for several months. I still remember looking at a Christmas present we bought for her that sat on a shelf in my closet for months after the holidays. 
second marriage. Threatened with losing custody of her remaining son, she gave up any interest in their modest house for sole custody of my half-brother. My mother's depressions became increasingly lengthy over the years. In manic spells, she fantasized of a joyful life in which she had a boyfriend. She would grow extremely angry when any of her sons tried to bring her back down to earth. She would almost inevitably shut off when depression hit and walk with her hands forward as a defense against the world. In this despondent state, she would return to the hospital. Now receiving disability benefits, she lives in a group house with other mentally disabled persons.

As my mother approaches senior citizenship, the Spanish myth that dominated her early adult. life has waned in her mind. She rarely, if ever, brings up the issue. She gets along very well with my wife's family, especially Grandma Lupe. And she has my children call her "Nana," a version of "grandma" common to some Mexican-American families. The persistence of her assimilationism, however, had a profound impact on her and our family.

I have no illusions that Angela Gallardo's assimilation experience is ordinary. Many Latinos have been much more successful at integrating themselves into the Anglo mainstream. Her story, however, illustrates that assimilation is a process entailing human pain and suffering. There are casualties. Though impossible to pinpoint the precise causes, my mother's psychological traumas at least in part were linked to her assimilation experience and her efforts to be "White."49 As researchers concluded in one study of schizophrenia,

without exception the experience that gets labeled schizophrenic is a special strategy that a person invents in order to live in an unlivable situation. In his life situation the person has come to feel he is in an untenable position. He cannot make a move, or make no move, without being beset by contradictory and paradoxical pushes and demands, pushes and pulls, both internally from himself, and externally from those around him. $\mathrm{He}$ is, as it were, in a position of checkmate. ${ }^{50}$

49. Cf. R.D. Laing, The Politics Of Experience 77-81 (1967) (explaining "double bind" theory of schizophrenia, which posits that inconsistent treatment of person predisposes persons toward schizophrenia); Gregory Bateson et al., Toward a Theory of Schizophrenia, 1 BEHAv. SCl. 251 (1956) (defining double bind as "situation in which no matter what a person does, he can't win"). For an in-depth analysis of the roles of gender, race, and poverty in the psychological status of women, see Patricia Perri Rieker \& M. Kay Jankowski, Sexism and Women's Psychological Status, in Mental Health, Racism, and Sexism 27 (Charles V. Willie et al. eds., 1995).

50. LAING, supra note 49 , at 78-79 (emphasis in original). 
In short, my mother faced an "unlivable situation" in which assimilation pressures placed her in permanent contradiction. Her illness was a response to a world sick with racism. Not surprisingly, due to assimilation and related pressures, racial minorities suffer a disproportionate amount of mental health problems in this country..$^{51}$ Often ignored in public discussion is that for some racial and ethnic groups, such as Asian-Americans, Latinos, and perhaps others, there are distinct limits on assimilation. We should not ignore either the assimilation limits or the toll the process takes on individuals.

The "melting pot" or "tossed salad" metaphor for immigrant assimilation fails to fully capture the experiences of racial minorities in the United States. Rather, racial minorities find themselves in a "ring of fire." Survival is possible if one remains near the middle of the figurative ring. The fire is hot and even those fortunate enough to avoid touching it and survive are hurt. All Latinos in the United States, even those who successfully navigate their way through the flames, are scarred. Many are not so lucky, however, but suffer immense pain, perhaps even self-destruction, as they get too close, or even touch the ring and are burned, sometimes beyond recognition. Like my grandmother and mother, they are unidentified, nameless casualties of the "ring of fire" known as the assimilation process.

II

RACE, ETHNICITY, AND NATIONHOOD FOR LATINOS: SOME ASSIMIL ATION LESSONS

The conventional wisdom in the United States has long been that immigrants should assimilate into the American mainstream. ${ }^{52}$ The "melting pot" metaphor depicts immigrants assimilating and acculturating into dominant society. Assimilation, however, historically has been far from voluntary. The often unspoken assumption is that immigrants to the United States have the affirmative obligation to assimilate. ${ }^{53}$

51. See generally Mental Health, Racism, AND Sexism, supra note 49 (collecting essays analyzing mental health issues raised by racism and sexism).

52. See generally Milton M. Gordon, Assimilation in AMERican Life (1964). I touch on some thoughts about Latino assimilation in a preliminary way in Kevin R. Johnson, Civil Rights and Immigration: Challenges for the Latino Community in the Twenty-First Century, 8 LA RAZA L.J. 42, 67-72 (1995).

53. See Kenneth L. Karst, Belonging to America 82-85 (1989); William M. Newman, American Pluralism 59-60 (1973); see also Sylvia R. Lazos, Deconstructing Homo[geneous] Americanus: The White Ethnic Immigrant Narrative and Its Exclusionary Effect, 71 TuL. L. REv. (forthcoming 1997) (analyzing assimilation "mandate" that society imposes on racial minorities as 
They should learn English, ${ }^{54}$ shed their "foreign" culture, and become "American." Tension exists, however, because some immigrants resist complete assimilation. ${ }^{55}$ Moreover, racial and other differences prevent full acceptance by dominant society of some minority groups. Consequently, scholars have forcefully challenged the application of the assimilationist ideal to racial minorities on philosophical, ${ }^{56}$ as well as historical, sociological, and psychological grounds. ${ }^{57}$ As George Martínez has observed, "[a]ssimilation can be thought of as the mirror image of multiculturalism." 58 Multiculturalism in effect represents a constructive response by people of color to the limits imposed by dominant society on their assimilation into the Anglo-Saxon mainstream.

In reality, all immigrant groups assimilate to some extent. ${ }^{59}$ The transitions, however, have not always been smooth. Virtually every wave of immigrants to the United States initially had difficulty adjusting to

part of cultural myth of homogeneity). For a highly romanticized view of immigrant assimilation in U.S. history, see Peter D. Salins, Assimilation, American Style (1997).

54. See, e.g., ARthur M. Schlesinger, JR., The Disuniting of America 107-10 (1992) (criticizing bilingual education spurred by a "flood of immigration from Spanish-speaking countries" and emphasizing that "a common language is a necessary bond of national cohesion"); see also Juan F. Perea, Demography and Distrust: An Essay on American Languages. Cultural Pluralism, and Official English, 77 MiNN. L. REv. 269 (1992) (analyzing history of movement for English language conformity in U.S.).

55. See Bill Ong Hing, Beyond the Rhetoric of Assimilation and Cultural Pluralism: Addressing the Tension of Separatism and Conflict in an Immigration-Driven Society, 81 CALIF. L. REV. 863 (1993) (analyzing tension between pro-assimilationists and cultural pluralists in modern immigration debate). I understand that there are many different sorts of "assimilation." See Kevin Brown, Do African-Americans Need Immersion Schools?: The Paradoxes Created by Legal Conceptualization of Race and Public Education, 78 IowA L REv, 813, 836 n.88 (1993) (distinguishing between "'structural assimilation' of the assimilating group into America's dominant lifcstyle [including integrated workplaces, neighborhoods and schools, andl 'cultural assimilation,' whereby the assimilating ethnic group adopts a shared language, similar behavior patterns, and a core set of attitudes, beliefs, and opinions"). Though political and economic assimilation may be something worth striving for by racial minorities, assimilation in the form of cultural abandonment is more problematic. See infra text accompanying notes 155-168 (suggesting strategies for political and economic assimilation by Latinos).

56. See George A. Martínez, Latinos, Assimilation, and the Law: A Philosophical Perspective, unpublished manuscript on file with California Law Review and La Raza Law Journal.

57. See Lazos, supra note 53.

58. Martínez, supra note 56, at 10; see John O. Calmore, Random Notes of an Integration Warrior, 81 MiNN. L. REV. 1441, 1474-76 (1997) (viewing multiculturalism as rejection of assimilation).

59. See Nathan Glazer \& Daniel Patrick Moynihan, Beyond the Melting Pot at xxxiii (2d ed. 1970) (noting that each immigrant ethnie group brought distinctive culture that was shaped by U.S. culture, thereby forging new identity). 
life here. ${ }^{60}$ Nonetheless, many European immigrants, such as those of the nineteenth century, eventually became almost indistinguishable from the rest of Anglo-American society. ${ }^{61}$ This has not been the case for immigrants of color. ${ }^{62}$

\section{A. Assimilation Latino Style}

The idealistic vision of the assimilation process has proven to be more problematic for people of color than for previous European immigrants. ${ }^{63}$ For example, in the late 1800 s, Chinese immigrants came to this country, contributed their labor, and later suffered the wrath of the political process. Congress passed a series of laws designed to exclude them from the United States. ${ }^{64}$ Among many other things, dominant U.S. society accused Chinese immigrants of refusing, or being physically or culturally unable, to assimilate. As the Supreme Court emphasized in rejecting a challenge to one of the exclusion laws, "[i]t seemed impossible for [the Chinese] to assimilate with our people or to make any change in their habits or modes of living." Similarly, the Court justified internment of persons of Japanese ancestry during World War II on the ground that "social, economic and political conditions ... have intensified [Japanese] solidarity and have in large measure prevented their assimilation as an integral part of the white population." ${ }^{.66}$

Like other peoples of color, Latinos in the United States have found it difficult to assimilate into the mainstream, whether they

60. See generally OsCaR HANDLIN, THE UPROOTED (2d ed. 1973) (documenting difficulties facing immigrants to United States).

61. See KARST, supra note 53, at 91-92.

62. See Lazos, supra note 53 (contending that today's immigrants of color have inappropriately been instructed to assimilate as past White ethnic immigrants did); $c f$. NATHAN GlazER, WE ARE All Multiculturalists Now 114-15 (1997) (recognizing that race has made it impossible for African-Americans to assimilate).

63. For further exploration of this theme, see Kevin R. Johnson, The New Nativism: Something Old, Something New, Something Borrowed, Something Blue, in ImMlgRants OUT! ThE New Nativism and the ANTi-Immigrant IMPULSE IN THE United States 165 (Juan F. Perea ed., 1997).

64. See Ronald Takaki, Strangers From a Different Shore 110-12 (1989) (recounting history of Chinese immigration to United States).

65. The Chinese Exclusion Case (Chae Chan Ping v. United States), 130 U.S. 581, 595 (1889).

66. Hirabayashi v. United States, 320 U.S. 81, 96 (1943) (footnote omitted). Some of these stereotypes about Asian-Americans survive to this day. See Robert S. Chang, Toward an Asian American Legal Scholarship: Critical Race Theory, Post-Structuralism, and Narrative Space, 81 Calif. L. Rev. 1241, 1252-58 (1993), 1 Asian L.J. 1, 12-19 (1993) (contending that modern antiAsian sentiment replays previous nativist epochs). 
immigrated to this country or not. ${ }^{67}$ Importantly, assimilation is not simply an issue for Latin-American immigrants. As a group, Latinos, even those with deep roots in the United States, have not fully assimilated into dominant U.S. society. ${ }^{68}$ This is true despite the government's efforts at various times in this nation's history to "Americanize" the Mexican community. ${ }^{69}$ The continued existence of separate and unequal Latino communities, as well as distinct Latino cultures independent of the Anglo norm, illustrates that assimilation, at least in its idyllic form, is not complete. Although some argue that intermarriage over time will facilitate Latino assimilation, ${ }^{70}$ Latinos remain outside the political and economic mainstream ${ }^{71}$ even though intermarriage has occurred for centuries.

Some current anti-immigration advocates accuse today's immigrants, particularly those from Latin America, of refusing to assimilate by maintaining their language and culture. ${ }^{72}$ Two Latino intellectuals with high media profiles, Linda Chavez ${ }^{73}$ and Richard Rodriguez, ${ }^{74}$ have added fuel to the fire by strongly encouraging "Hispanics" to assimilate and criticizing leaders who, they claim, encourage ethnic separation.

There are at least two flaws with this claim. First, Latinos do assimilate into U.S. society to some degree. Second, the proassimilationist argument judges people of color by the experiences of White immigrants, when Anglo society has never accorded Latinos such

67. See Carlos Villarreal, Culture in Lawmaking: A Chicano Perspective, 24 U.C. DAvIS L REv. 1193, 1196-1215 (1991) (analyzing psychological and other costs to Chicanos exacted by assimilation pressures); see also Rachel F. Moran, Foreword-Demography and Distrust: The Latino Challenge to Civil Rights and Immigration Policy in the 1990s and Beyond, 8 LA RAzA L.J. 1, 13-24 (1995) (contrasting immigration experience of Latinos with other groups and noting emergence of transnational identity among some Latin-American immigrants, particularly those from Mexico).

68. See generally George J. Sánchez, Becoming Mexican American (1993) (analyzing Mexican cultural adaptation without substantial economic mobility in Los Angeles).

69. See Bill ONG HiNG, To Be AN AMERICAN 19-20 (1997) (summarizing efforts).

70. See, e.g., ChAvez, supra note 12, at 139-40; see also infra text accompanying notes 188189 (discussing why optimism about intermarriage curing racial woes is misplaced).

71. See Luis Angel Toro, "A People Distinct from Others": Race and ldentity in Federal Indian Law and the Hispanic Classification in OMB Directive No. 15, 26 TEx. TeCH L REv. 1219, 1249-51 (reviewing evidence of the lack of Latino assimilation).

72. See, e.g., Peter Brimelow, Alien Nation (1995) (advocating drastic reduction in immigration levels because of alleged refusal of non-Anglo Saxon immigrants to assimilate); Richard D. LAmM \& GARY Imhoff, The Immigration Time Bomb 76-98 (1985) (contending that Latin-American and other immigrants refuse to assimilate and create "the splintered society"). In the same vein, the United States Commission on Immigration Reform recently recommended that the Immigration \& Naturalization Service pursue "Americanization" efforts by promoting naturalization. See U.S. Comm'n on Immigr. Reform, Legal Immigration: Setting Priorities 175-200 (1995).

73. See Chavez, supra note 12.

74. See RodRIGUEZ, supra note 13. 
privileged status. A fundamental truth is that White ethnic immigrants of generations past found it easier to assimilate than immigrants of color. ${ }^{75}$

\section{Latinos Assimilate!}

Despite the attacks of the pro-assimilationists, immigrants from Latin America in fact assimilate and adapt to some degree to life in the United States. By necessity, Mexican immigrants, even if native Spanish speakers, tend to learn English. ${ }^{76}$ In California, Latino men have a higher labor market participation rate than any other racial group, including Anglos." Importantly, "Latinos appear to have behaviors and values very similar to those held by middle class Anglos in the areas of family life, work ethic, health outcomes and education."78

In short, Latinos assimilate to some degree. Full political and economic assimilation, however, eludes the community. Barriers to Latino assimilation explain this phenomenon.

\section{Limits on Latino Assimilation}

As the twentieth century comes to a close, the perceived assimilation problem has grown with the changing demographics of immigration. ${ }^{79}$ Full acceptance of immigrants of color by dominant society has proven difficult due to their physical, cultural, and linguistic differences from the Anglo norm. In many ways, the latest cohorts of Asian and Latin-American immigrants face many of the same hurdles to assimilation that Chinese and Japanese immigrants faced a century ago. Even as

75. See generally Lazos, supra note 53.

76. See Rodolfo O. DE la Garza et AL., Latino Voices 42 (1992) [hereinafter Latino VoICES] (reporting survey results showing that over $60 \%$ of U.S.-born Mexican-Americans spoke only English or more English than Spanish in the home); see also Hing, supra note 55, at 877 ("Study after study demonstrates... that the vast majority of immigrants take on cultural traits of the host community.").

77. See David E Hayes-Bautista ET AL., No Longer a Minority 11 fig.2 (1992) (presenting labor market participation data from 1940-1990).

78. Id. at 33 .

79. Until 1965, the national-origin quota system in U.S. immigration laws limited immigration from many developing, non-White nations and favored immigration from northwestern Europe. See Stephen H. Legomsky, Immigration, Equality and Diversity, 31 Colum. J. TransNat'L L. 319, 32630 (1993). Lifting the quotas in 1965 allowed a more diverse group of immigrants to come to the United States. See Jeffrey S. Passel \& Barry Edmonston, Immigration and Race: Recent Trends in Immigration to the United States, in 1Mmigration AND ETHNICITY 31 (Barry Edmonston \& Jeffrey Passel eds., 1994) (studying impact of immigration on racial and ethnic composition of U.S. population). 
the "new" immigrants acculturate, they remain different in important ways from the dominant Anglo population.

Anglo society views Latinos, with their Spanish language and surnames, their non-Anglo-Saxon culture, and their different physical appearance, as foreign and different. "[A]n important part of the public image of the Latino is the Latino as alien: an immigrant, a recent arrival, a foreigner not really belonging to, or in, America." ${ }^{80}$ Latinos born in the United States may be treated as foreigners, ${ }^{81}$ even when a similarly situated German- or Irish-American almost certainly would not be. Able to more easily blend into the mainstream, European immigrants shed their "foreignness" more quickly than people of color.

Even the experiences of the "most assimilated" Latinos illustrate the limits of assimilation. Ardent assimilationist Linda Chavez resigned as president of U.S. English, an organization devoted to ending bilingual education and establishing English as the official language, after a crude anti-Latino memorandum written by the organization's founder came to light. ${ }^{82}$ The memorandum questioned whether "Hispanics" could be educated, spoke of the "Latin American onslaught," and expressed concern over the fertility rates of Latinos: "[P]erhaps this is the first instance in which those with their pants up are going to get caught by those with their pants down!"83

Similarly, Professor Margaret Montoya has eloquently described how Chicanas wear "masks" in interactions with the Anglo mainstream, and how she herself did so as a student at Harvard Law School. ${ }^{84}$ The much-publicized story of Joe Razo, a Chicano attending Harvard College who fashioned himself as a "homeboy," and was later

80. Perea, supra note 45 , at 977 . Asian-Americans aiso are frequently categorized as "foreign." See Pat K. Chew, Asian Americans: The "Reticent" Minority and Their Paradoxes, 36 WM. \& MARY L. REV. 1, 33-38 (1994) (discussing labelling of Asian-Americans as "foreigners"); Cynthia Kwei Yung Lee, Race and Self-Defense: Toward a Normative Conception of Reasonableness, 81 Minn. L. REv. 367, 429-38, 441-52 (1996) (analyzing impact of "Asian-as-Foreigner," "Latinoas-Foreigner," and "Latino-as-Criminal" stereotypes on criminal law of self-defense).

81. See, e.g., Johnson, supra note 10 (describing incident in which Latino member of Congress Luis Gutierrez was told by law enforcement officer at Capitol to go back to where he came from and discussing generally treatment of Latinos as foreigners); Kevin R. Johnson, Free Trade and Closed Borders: NAFTA and Mexican Immigration to the United States, 27 U.C. DAvIs L. REv. 937, 949-50 (1994) (recounting incident at conference where an audience member assumed fifth generation Chicano speaking on human rights abuses along U.S.-Mexico border was an immigrant).

82. See Chavez, supra note 12 , at $91-92$ (describing incident).

83. Id. (quoting memorandum).

84. See Montoya, supra note 43, at 192-201, 206-09; see also Espinoza, supra note 16, at 1886 ("Minority legal scholars, in order to get where they are, have spent a lifetime disguising their difference, hoping that the difference will not disqualify them froin achievement." (footnote omitted)). 
convicted of committing armed robberies during summer vacation, demonstrates the precarious nature of Latino assimilation among those who appear to be the most assimilated. ${ }^{85}$

Full-fledged assimilation may not be possible even for Latinos of mixed backgrounds, like myself, who do not necessarily "look" Latino. As Greg Williams and Judy Trent-Scales highlight in writing about their experiences as African-Americans who appear White, it is not easy to wash your hands of your background. For me, having been raised by a Chicana and growing up with Latinos at times made blending in with the Anglo mainstream a stressful experience. ${ }^{86}$ Danger always exists that comments made in my presence will irritate, hurt, or simply make me uncomfortable. ${ }^{87}$ As the story with which I began this article suggests, some Anglos may see me as part of their club and therefore assume that I am willing to join them in belittling Latinos. ${ }^{88}$ Of course, some Latinos not of mixed backgrounds have similar experiences. My fair-skinned Mexican-American wife, for example, had a well-meaning fellow student tell her in college that she did not "10ok" Mexican, a seemingly innocuous comment likely meant as a compliment that has stayed with her over the years. Now, what did this person mean, that Virginia was light-skinned and that Mexicans were supposed to be dark? That she was attractive and that Mexicans were not? Or, maybe that Mexicans looked different from the norm and she looked "normal"? None of the possible interpretations rescue the comment from being offensive.

\section{a. A Diversity of Assimilation Experiences}

Diversity within the Latino community helps explain why some Latinos more easily assimilate than others. Phenotype is an important assimilation variable. Fairer-skinned Latinos, for example, often find

85. See Ruben Navarrette, Jr., A Darker Shade of Crimson 117-38 (1993) (describing incident and pressures on Chicanos at Harvard College).

86. Members of other minority groups have had similar experiences. See Hing, supra note 55, at 891-92 (recounting sentiments of some African-Americans who, to avoid stress, prefer living in predominantly African-American communities as opposed to integrated ones).

87. See Davis, supra note 28 (analyzing "microaggressions," the subtle slights and putdowns suffered by African-Americans, and perception of law as series of microaggrossions); Chester M. Pierce, Stress Analogs of Racism and Sexism: Terrorism, Torture, and Disaster in Mental Health, in Mental Health, RacisM, AND SEXISM 277, supra note 49, at 281-82 (stating that "[p]robably the most grievous offensive mechanisms spewed at victims in racism and sexism are microaggressions... [,] subtle, innocuous, preconscious, or unconscious degradations, and putdowns").

88. See infra text accompanying notes $229-232$ (offering personal examples of similar indignities). 
assimilation easier than other Latinos. They shed their "foreignness" and blend into the norm more easily than the more indigenouslooking. ${ }^{89}$ For example, Cuban-Americans, a group with many fairskinned persons, generally speaking have found it easier than other Latino groups to assimilate economically, politically and socially. ${ }^{90}$ In stark contrast, Puerto Ricans, some of whom are Black, are the Latino national origin group least likely to be assimilated in this way.1

Besides physical variation, there are social and cultural barriers to full integration by Latinos into U.S. society. To assimilate fully, Latinos would need for their race to become a non-issue, transparent like Whiteness. ${ }^{22}$ To do this, however, a person of Latino ancestry must ignore and eliminate any consciousness of his or her background and strive to be "White" at all costs. Some Latinos are more willing to make this sacrifice than others. One can only wonder about the damage to an individual's psyche of living a hidden life that includes suppressing your Latino identity while fearing that some day somebody might discover you are an Anglo impostor. ${ }^{93}$

In short, Latino diversity, which will be analyzed more thoroughly later in this article, results in different assimilation potentials. ${ }^{94}$ It also results in a wide variety of life experiences among Latinos.

89. See infra text accompanying notes 127-134 (analyzing impact of phenotype on life experience), 196-207 (analyzing concept of Latinos "passing" as White).

90. See María Cristina García, Havana USA 108-19 (1996). This may be in part due to government assistance provided to political refugees from Cuba not provided, for example, to Mexican immigrants. See Silvia Pedraza-Bailey, Cuban Political Immigrants and Mexican Economic Immigrants: The Role of Government Policy in Their Assimilation, in HISPANtc MIGRATION AND THE UNITED STATEs 68 (Gastón Fernandez et al. eds., 1987). Distinctions, however, should be made between different waves of Cuban immigrants. Cubans who came before 1980, who were mostly White, experienced greater acceptance in the United States than Cuban immigrants who came over in the Mariel Boatlift, which included a significant number of Black Cubans. See infra text accompanying note 134 (discussing negative reaction to Mariel Cubans in part attributable to fact that many were Black).

91. See Glazer \& MOYNIhAN, supra note 59, at 86-136 (analyzing assimilation difficulties Puerto Ricans have experienced in New York City); see also Chavez, supra note 12, at 139-59 (recognizing "Puerto Rican exception" to Latino assimilation).

92. See Flagg, supra note 5, at 957 (discussing transparency concept). For analysis of the construction of Whiteness, see Ruth FranKenberg, White Women, Race Matters (1993); laN F. Haney López, White By Law (1996); David R. Roediger, Towards the Abolition of WHITENESS (1994).

93. See infra text accompanying notes 196-207 (discussing costs of "passing").

94. See infra text accompanying notes 122-169 (analyzing this phenomenon). 


\section{b. Complications of the Border}

One characteristic of Mexican immigration differentiates it from the immigration experience of other groups: the United States and Mexico share a border thousands of miles in length. Due in no small part to this geographic proximity, a large population of unnaturalized Mexican immigrants live in the United States. ${ }^{95}$ Although some may have assimilated to some degree culturally and otherwise, they are not integrated into the political process. ${ }^{96}$ In addition, a significant number of Mexican immigrants view naturalization, which bestows citizenship and allows full political participation, as the mark of a traitor. They live by the slogan, "Born a Mexican, die a Mexican." 97 Many Mexican citizens resist naturalization for a number of other reasons besides allegiance to Mexico, including the complexity and length of the process. ${ }^{98}$ Whatever the cause, until the political and economic integration of Latino noncitizens occurs, "assimilation" will remain incomplete. ${ }^{99}$

In short, a portion of the Mexican population in the United States resist full assimilation into the mainstream because of their transnational identity. ${ }^{100}$ Proximity to Mexico facilitates the formation and perpetuation of that identity.

95. See Johnson, supra note 52, at 51-55 (discussing implications of low naturalization rates of Mexican immigrants on Latino electoral participation and suggesting possible solutions); see also U.S. Dep'T OF Justice, 1994 Statistical Yearbook of THE Immigration and Naturalization Service 132 Tbl. K (1996) (showing data that, for immigrants admitted in fiscal year 1977, naturalization rate was only $17.6 \%$ for immigrants from Mexico compared to over $60 \%$ for immigrants from Soviet Union, the Philippines, and China).

96. See Rodolfo O. de la Garza \& Louis DeSipio, Save the Baby, Change the Bathwater, and Scrub the Tub: Latino Electoral Participation After Seventeen Years of Voting Rights Act Coverage, 71 TEx. L. REv. 1479, 1511-13 (1993) (analyzing negative impact of large noncitizen population and high immigration levels on Latino electoral participation).

97. Consider in this regard Richard Rodriguez's description of his father's naturalization:

[W] hen he decided to apply for American citizenship, my father told no one, none of his friends, those men with whom he had come to this country looking for work. American citizenship would have seemed a betrayal of Mexico, a sin against memory. One afternoon, like a man with something to hide, my father slipped away. He went downtown to the Federal Building in Sacramento and disappeared into America.

Richard Rodriguez, Days of Obligation 50 (1992).

98. See generally DAVID S. NORTH, THE LONG GRAY WELcOME (1985) (analyzing deficiencies in naturalization process); U.S. COMM'N ON IMMIG. REFORM, supra note 72, at 184-200 (recommending that Immigration \& Naturalization Service reduce delays in process).

99. See KARST, supra note 53 , at 92-94.

100. See Moran, supra note 67 , at $13-24$ (analyzing this identity). 
c. The Intersection of Assimilation, Identity Choice, Latino Diversity, and Anglo/Latino Belonging

Assimilation cuts across several issues of race, ethnicity, and nationhood for Latinos. The efforts of some Latinos to "pass" as Spanish, and therefore "White," represent an attempt to avoid the negative attributes of being classified as a racialized Other in an Anglo-dominated world. My affiliation as a Latino, even though I have only one brown parent, illustrates the volitional nature of racial identity for some. In addition, the oft-ignored diversity in the Latino community helps explain why the life experiences of Latinos differ so, especially why some find it easier to assimilate than others. Assimilation, racial choice, and Latino diversity all come into play when I pose the question of where mixed Anglo/Latino persons-half-brown, halfWhite-fit into the heated racial identity politics of the modern United States.

\section{B. Deciding to Be Latino?}

A considerable body of academic commentary focuses on the voluntary adoption of a racial or ethnic identity. The title of Mary $\mathrm{C}$. Water's book-Ethnic Options: Choosing Identities in America ${ }^{101}$ nicely captures the essence of the concept. As Ken Karst has observed,

identity itself is a myth-a myth of origin, or destiny, or both.

We "make up people," inventing categories, giving each category not only a label but an imagined history and an imagined behavioral script-and then deciding, Yes or No, whether particular individuals should be assigned to the category. ${ }^{102}$

Choice in living a myth, however, is less available for some than for others. "[I]n every circumstance choices are exercised not by free agents or autonomous actors, but by people who are compromised and constrained by the social context." 103 Indeed, society thrusts a racial identity on minorities of certain phenotypes. It greatly overstates

101. WATERS, supra note 17.

102. Kenneth L. Karst, Myths of Identity: Individual and Group Portraits of Race and Sexual Orientation, 43 UCLA L. REv. 263, 283-84 (1995) (footnote omitted). The concept of race as a volitional construct is inconsistent with the conventional wisdom that race is an "immutable characteristic," which underlies the Supreme Court's jurisprudence under the Equal Protection Clause of the Fourteenth Amendment of the U.S. Constitntion. See John HarT ELY, Democracy AND Distrust: A THEORY OF Judicial REviEw 150-55 (1980) (analyzing importance of "immutable characteristic[sl" in equal protection analysis).

103. Ian F. Haney López, The Social Construction of Race: Some Observations on Illusion, Fabrication, and Choice, 29 HaRv. C.R.-C.L. L. REv. 1, 47 (1994). 
matters, for example, to suggest that a dark-skinned African-American and a fair-complexioned Latino have the same "choice" with respect to racial identification. Society treats those with dark skin as "Black"104 regardless of their desired identity, and, depending on other variables, may treat the fair Latino as White. ${ }^{105}$

As this suggests, discrimination against Latinos based on physical appearance may thwart their ability to voluntarily adopt a racial identity other than one dominant society assigns them. ${ }^{106}$ In essence, Black Latinos, or those with physical features often linked with indigenous peoples, have a socially constructed "race" imposed upon them. Fairer Latinos who do not literally look like "people of color" have different experiences and different choices. ${ }^{107}$ In a similar vein, Latinos with Anglo surnames generally have more choice than people with Spanish surnames.

Constraints on choice are reflected in the surveys showing that African-Americans and Mexican-Americans, even if of mixed ancestry, are more consistent in ethnic affiliation than White ethnics over time. ${ }^{108}$ It is noteworthy, however, that significant differences exist in identification among Latinos along national origin lines. Puerto Ricans are more consistent in ethnic affiliation than Mexicans, who in turn more consistently maintain their identification than Cubans. ${ }^{109}$ It is no coincidence that Puerto Ricans, the most economically deprived of all Latino national-origin groups, ${ }^{110}$ include a significant Black population, and that

104. See id. at 9; Karst, supra note 102, at 307. Although physical appearances may be changed to some extent, see HANEY LóPEZ, supra note 92, at 191-92, there are limits. Efforts to straighten one's hair, for example, will not change the fact for many African-Americans that society treats them as Blacks.

105. See Berta Esperanza Hernández Truyol, Building Bridges-Latinas and Latinos at the Crossroads: Realities, Rhetoric, and Replacement, 25 Colum. Human RTS. L. REV. 369, 427 (1994) (noting that some Latinos "appear 'White' in the 'Anglo' sense" (footnote omitted)).

106. See WATERs, supra note 17 , at 156.

107. See infra text accompanying notes 127-134 (analyzing impact of physical appearance on Latino assimilation).

108. See W ATERS, supra note 17, at 37-38. Blacks and Mexican-Americans gave a consistent response $94.2 \%$ and $88.3 \%$ of the time, respectively, lrish-Americans gave a consistent response $57.1 \%$ of the time, and persons of English, Scottish, and Welsh heritage lagged behind that at $55.1 \%$. See id.

109. Id. at 38 (reporting that over $96 \%$ of Puerto Ricans, over $88 \%$ of Mexicans and over $83 \%$ of Cubans consistently responded to question about ethnic identity).

110. See infra text accompanying notes $137-138$ (citing authorities analyzing average income of Puerto Ricans compared to other Latino national-origin groups). 
many Cuban-Americans, the most well-off economically of all Latinos, have light complexions. ${ }^{111}$

Even when identity choice exists for certain Latinos, the adoption of a racial identity is not completely painless or free of constraints. Finding one's racial identity probably is one of the most difficult decisions in life. Besides the emotional turmoil of coming to grips with one's background, ${ }^{112}$ identity selection exposes a person to the judgment of others. Risks for Latinos include rejection for refusing to assimilate and challenge as an "impostor" out for personal gain through such programs as affirmative action. ${ }^{113}$

Persons of mixed Anglo/Latino backgrounds who appear White, as well as all Latinos who "look" White, have more choice of racial identity than other Latinos. Choices, of course, are circumscribed by life experiences. Denial of one's background-relatives and friends, upbringing, culture, and the like-exacts costs. ${ }^{114}$ Benefits exist as well. Acquaintances of mine with mixed backgrounds from high school, college, and law school have adopted White identities, though at times some have checked the Latino box for affirmative action purposes. ${ }^{115}$

Due to the latitude in adopting a racial identity, a wide range of responses to mixed Latino-Anglo background exist. Denial, which as my mother's experience suggests is not limited to Latinos of mixed parentage, is at one end of the spectrum. I have known mixed Anglo/Mexican-Americans of my generation who minimized, ignored, or denied any Latino identity. For them, the benefits of Whiteness outweighed the psychological and other costs of denying their ancestry. The transparency of Whiteness allows them to avoid confronting issues of race on a regular basis. ${ }^{16}$ As my mother and grandmother understood, there are advantages to being White in Anglo society, ${ }^{117}$ though they paid dearly in unsuccessfully attempting to assume a White identity.

111. See infra text accompanying notes \& notes 137-138 (noting differences in income distributions and political views among Cubans, Puerto Ricans, and Mexican-Americans reflected in survey data).

112. See, e.g., WiLliams, supra note 23 (describing his experiences in this regard).

113. See infra text accompanying notes 208-214 (analyzing this phenomenon in detail).

114. See infra text accompanying notcs 196-207 (analyzing costs of "passing").

115. See JoHNSON, supra note 84-85 and accompanying text (describing some examples among student body at Harvard Law School).

116. See supra text accompanying note 5 (describing "transparency" of Whiteness).

117. See generally Cheryl 1. Harris, Whiteness as Property, 106 HaRv. L. REv. 1707 (1993) (analyzing Whiteness as valuable property interest). 
At the other end of the spectrum is a complete embrace of an exclusively Latino identity. Few concrete benefits and many costs accrue to those who identify as Latino. Despite the costs, some Latinos choose this route. For me, the constant questioning of my identity is one obvious cost. Rarely a day goes by in which my identity is not openly placed in question. Many assume that I am White because of my surname and appearance and wonder how it is possible that a Latino could be named Johnson, how I could have children named Teresa, Tomás, and Elena, or why I am so interested in "Latino" issues.

Some might claim, however, that identifying as Latino provides one concrete benefit: eligibility for affirmative action. ${ }^{118}$ These charges can come from diverse quarters. Some Anglos complain that these Latinos refuse to assimilate and seek only to "cash in" on affirmative action. Some Latinos contend that the self-identified Latino of mixed heritage is only a "check-the-box" Latino in search of affirmative action benefits. Both charges have been leveled at me in my lifetime. Such accusations ignore the fact that Latinos have seen rather insignificant gains through affirmative action. ${ }^{119}$

The myth remains, however, that there are many affirmative action benefits to be gained by identifying as Latino. I admittedly know persons of mixed Anglo/Latino background who identified their heritage only for purposes of affirmative action in college and law school admission and may have benefited because of that identification. However, the number of Latinos in this group is so small that other racial justice issues unquestionably are more worthy of our attention.

I exercised a good deal of choice in embracing a MexicanAmerican identity. Facilitated by an Anglo surname, "passing" as White has been possible in many circumstances. I visited many a crossroad where I could have ignored or downplayed my background or simply identified as White without words spoken or an eyebrow raised. Nonetheless, to say that I had "free" choice would greatly exaggerate matters. I grew up with a Mexican-American mother and grandmother

118. Affirmative action programs are designed to "redress[] past injury combatting persistent prejudice, or pursu[e] goals of diversity and integration" in employment, education and other settings. LAURenCE H. Tribe, American Constitutional LaW, $\$ \S 16-22$, at 1521 (2d ed. 1988) (analyzing Supreme Court decisions on affirmative action; see also Oppenheimer, supra note 29 (discussing history and modern need for affirmative action programs); Martha S. West, The Historical Roots of Affirmative Action, 10 LA RAZA L.J. (forthcoming 1997) (summarizing development of modern affirmative action programs).

119. See, e.g., Michael A. Olivas, The Education of Latino Lawyers: An Essay on Crop Cultivation, 14 Chicano-Latino L. Rev. 117 (1994) (presenting data showing relatively few Latinos in law teaching and as law students despite affirmative action). 
and, until the seventh grade, in a mixed working class Anglo/MexicanAmerican community. To erase or ignore that part of my background would have been painful, if not impossible. The fact that my wife is a Mexican-American contributed to my continued self-identification, and deflected challenges to my identity. ${ }^{120}$

My brother made a different choice. Born with a more Anglo appearance (blue-eyed, blond) than I, he recognizes our family history and treats it as just that-a historical fact with little relevance to daily life. ${ }^{121}$ His is not the denial that marked my mother's identity. Nor is it the open embrace of a Latino identity.

In conclusion, some Latinos have some choice in deciding to assimilate and adopt a White identity. The degree of choice varies in part depending on physical appearance and other characteristics. This choice, which in turn varies because of Latino diversity, should not be ignored for it greatly affects the assimilation experiences of Latinos.

\section{Latino Diversity}

Although many consider Latinos to be a monolithic group, ${ }^{122}$ Latinos in the United States are extremely heterogeneous, composed of persons of Mexican, Cuban, Puerto Rican, Central-American, and other Latin-American ancestry. ${ }^{123}$ National origin diversity, which varies by region in this country, ${ }^{124}$ is simply the beginning. Latinos differ widely in terms of race, immigration status, duration in this country, the circumstances under which they came, social class, linguistic abilities, and

120. As others have observed, choice of marriage partners may affect one's racial identity. See, e.g., HANEY LÓPEZ, supra note 92, at 192.

121. My half-brother, with a phenotype similar to mine, took the same route as my brother.

122. See Johnson, supra note 52, at 67-72 (summarizing Latino diversity). For a demographic breakdown of the Latino community, see Hernández Truyol, supra note 105, at 383-96.

123. See Alejandro Portes, From South of the Border: Hispanic Minorities in the United States, in IMMIGRATION RECONSIDERED 160-61 (Virginia Yans-McLaughlin ed., 1990) (analyzing diverse experiences of Mexican-Americans, Puerto Ricans, and Cuban-Americans in U.S.); see also Alex M. Saragoza et al., History and Public Policy: Title VIJ and the Use of the Hispanic Classification, 5 LA RAZA L.J. 1, 3-4, 25-27 (1992) (noting diversity among persons who fall within category of "Hispanics" and the implications of Hispanic diversity).

There is hetcrogencity in other minority communities as well. See generally William E Cross, JR., Shades of BlaCK (1991) (analyzing diversity in African-American community); Bill ONG Hing, Making and Remaking Asian America Through Immigration Policy, 1850-1990 (1993) (analyzing how immigration policies have affected development of various Asian-American communities in United States).

124. For example, in Califoruia in 1990, 80\% of the Latino population was Mexican-American, compared to $2 \%$ Puerto Rican and $1 \%$ Cuban. See Fredric C. GeY et Al., California Latina/Latino Demographic Data BooK 9 Tbls. 1-3 (1992). Latino population demographics in Florida and New York differ dramatically. 
culture, to name a few salient characteristics. ${ }^{125}$ Diversity exists even in the types of Spanish spoken among Latinos who speak Spanish. ${ }^{126}$

My nuclear family exemplifies the diversity: a half-MexicanAmerican, half-Anglo man with a knowledge of some Spanish who looks more White (at least to some) than not, married to a MexicanAmerican woman who speaks some Spanish, with three children who are three-fourths Mexican-American, two with differing shades of blond hair, blue eyes and light skin, and one with dark brown hair, brown eyes and a dark complexion.

Latino diversity has a number of consequences that are frequently overlooked. The heterogeneity contributes to wide variation of assimilation potentials among Latinos. In essence, some Latinos find it easier than others to assimilate into the Anglo mainstream. This range of assimilation potentials results in a panoply of assimilation experiences in the Latino community, which in turn contributes to many different perspectives among Latinos on the racial status quo in the United States.

\section{Physical Appearance}

Latinos vary widely in terms of physical appearance. Some have a more Anglo appearance while others look more indigenous; still others are Black. Phenotype also varies within particular national origin groups. For many Mexican-Americans, for example, "the Indian racial types predominate. Most are dark of complexion with black hair, traits inherited in large part from their Indian ancestors. But many are blond, blue-eyed and 'white,' while others have red hair and hazel eyes."127

As a result, experience with discrimination based on physical appearance varies greatly among Latinos. While it is a relatively minor problem for some, it looms larger in the lives of Latinos with more

125. See Portes, supra note 123, at 160-61; see also JUlian SAMORA \& PATricia VANDeL Snmon, A History of the Mexican-American People 8 (rev. ed. 1993) (observing "great diversity of physical, social, and cultural traits" among Mexican-American community); Saragoza et al., supra note 123, at 4 ("[T]here are no indelible physical characteristics, language, or cultural forms that are shared by all of the people south of the U.S.-Mexico border that would invariably unify them under one ethnic or racial term.").

Latinos are diverse with respect to other characteristics as well. For example, although Catholicism is the dominant religion in the Latino community, Latinos practice many different religious faiths. See LATINo VoICES, supra note 76, at 37 ("Among Latino [survey] respondents who had a religious affiliation, between 60 and 80 percent were Catholic ....").

126. See Alexandre Rainof, How Best to Use an Interpreter in Court, 55 CAL. ST. B.J. 196 (1980) (mentioning existence of 19 major Spanish dialects and offering examples of variations among them); see, e.g., Hernández Truyol, supra note 105, at 406-07 (telling story about the different meaning of Spanish word "tortilla" in Caribbean and Southwest).

127. SAMORA \& SMON, supra note 125 , at 8 . 
indigenous appearances. ${ }^{128}$ Put simply, differences in physical appearance affect Latino life experiences. For example, Mexican-Americans who fit the stereotype-dark-complexioned with more indigenous features-are more likely to be treated as "minorities" in everyday life than other Mexican-Americans. ${ }^{129}$ They are more likely to be stopped, questioned, or worse, by immigration authorities in border communities. Having the physical appearance of a stereotypical Mexican can lead to distinctly "special" treatment by the Border Patrol. ${ }^{130}$

While not subject to discrimination by Anglo society on account of physical appearance, light-skinned Mexican-Americans may suffer "microaggressions," such as racial insults of Mexican-Americans in their presence. ${ }^{131}$ They also may be challenged by their fellow Mexican-Americans as being "too White." The term gabacho, slang for Anglo, has been directed by some Mexican-Americans at other Mexican-Americans. ${ }^{132}$ Perhaps it is simply my own self-consciousness,

128. See Carlos H. Arce et al., Phenotype and Life Chances Among Chicanos, 9 Hispanic J. BEHAv. SCI. 19 (1987) (concluding that Mexican-Americans with European physical appearance have enhanced "life chances" than Mexican-Americans with indigenous features); Martha Menchaca, Chicano Indianism: A Historical Account of Racial Repression in the United States, 20 AM. ETHNoLog1st 583, 599 (1993) (scrutinizing history of laws applied to Mexicans and concluding "that the skin color of Mexican-origin people strongly influenced whether they were to be treated by the legal system as White or as non-White"); Edward E. Telles \& Edward Murguia, Phenotypic Discrimination and Income Differences Among Mexican Americans, 71 Soc. ScI. Q. 682 (1990) (finding that, although Mexican-American incomes in all phenotypic groups lag far behind those of non-Hispanic Whites, earnings of Mexican-American males with dark and native American phenotype receive significantly lower income than lighter Mexican-American males with more European phenotype).

129. See J. Jorge Klor de Alva, Telling Hispanics Apart: Latino Sociocultural Diversity, in THE HiSPANic EXPERIENCE in THE United STATes 106, 114 (Edna Acosta-Belén \& Barbara R. Sjostrom eds., 1988); see also Rodriguez, supra note 13, at 115-16 (describing liarsh treatment afforded darker skinned sister, taunted in grade school and troubled in college when dark-skinned foreign students from Turkey and India found her attractive and her relief that her children were light).

130. See, e.g., González-Rivera v. INS, 22 F.3d 1441, 1447 (9th Cir. 1994) (finding that Border Patrol stopped undocumented Mexican because of his "Hispanic appearance"); Lee Romney, Over the Line?, L.A. Times (San Gabriel Valley ed.), Sept. 2, 1993, at J1 (reporting that Eddie Cortez, conservative Republican and third-generation Mexican-American mayor of small southern California city, was stopped by the Border Patrol apparently because he fit "the profile" of an undocumented immigrant); see also Elvia R. Arriola, LatCrit Theory, International Human Rights, Popular Culture and the Faces of Despair in INS Raids, 28 MiAm INTER-AM. L. Rev. 245, 256-63 (1996-97) (analyzing impact of INS raids on Mexican immigrants and Mexican-Americans); supra note 81 (offering examples of treatment of Latinos as foreigners).

131. See supra text accompanying notes 86-88 (discussing phenomenon of microaggressions).

132. See Rick P. Rivera, A Fabricated MexicAN 79-81 (1995) (describing fictional account of Mexican-American accusing another one of being a "gabacho," slang for White). Pocho is another derogatory term directed at some Mexican-Americans by other Mexican-Americans. See Richard Delgado, Rodrigo's Fourteenth Chronicle: American Apocalypse, 32 HARV. C.R.-C.L. L. 
but many Latinos of mixed heritage at various times feel less than fully accepted by the Latino community. Because being rejected by Latinos does not necessarily mean full acceptance by Anglos, such persons may feel as if they do not belong fully in either the Anglo or Latino worlds.

Moreover, because of the stigmatization of African-Americans in the United States, Latinos who are Black face an entirely different set of obstacles. Black Latinos cannot "pass" as White and may be classified by society not as Latino, but as African-American. As some Puerto Ricans and Cubans have experienced, they find it difficult to assimilate and are, on the average, less well-off socio-economically than other Latinos. ${ }^{133}$ The negative reaction, including by some Cuban-Americans, to the Cuban refugees who came to this country in the Mariel boatlift of 1980 stemmed in part from the fact that many were Black. ${ }^{134}$

Physical appearances of different Latinos affect their assimilation experiences in the United States. It is a sad truth that the darker the skin, the more formidable the obstacles to assimilation.

\section{National Origin}

Latinos in the United States can trace their ancestry throughout Latin America. ${ }^{135}$ Despite this fact, political efforts in recent years have tended to homogenize the Latino experience. Pan-Latino coalition building, however, often confronts national origin allegiances that trump any collective "Latiuo" identity. Tensions among and between various Latino groups at times run high. ${ }^{136}$ Some are political in nature. For example, Cuban-Americans are often said to be more politically conservative than other Latinos. Some tensions are more class-driven, but with a national origin overlay. Because the income distribution of persons of Mexican, Puerto Rican, and Cuban ancestry in the United States varies substantially, ${ }^{137}$ one is not surprised to learn of differences in political

REv. 275, 299 \& n.115 (1997) (mentioning that pocho is Spanish slang for person of Mexican ancestry "who does not speak Spanish and has lost touch with his or her roots").

133. See infra notes $137-38$ (citing authorities).

134. See GARcía, supra note 90 , at 68 (noting that $15-40 \%$ of Marielitos were Black compared to $3 \%$ of $1959-73$ immigrant population from Cuba); see also EARL SHORRIS, LATINOS 64 (1992) (noting that first wave of Cubans were mostly White and educated while many in the later group were Black with little education).

135. See supra text accompanying note 123 .

136. See, e.g., Hernández Truyol, supra note 105, at 411 (relaying story of Cuban-American being treated as outsider by other Latinos).

137. See Latino Volces, supra note 76 , at 54 (showing that, at time of survey, $25.5 \%$ of Mexicans, $45 \%$ of Puerto Ricans, and $19.7 \%$ of Cubans surveyed earned less than $\$ 13,000$ and that $11 \%$ of Mexicans, $4.6 \%$ of Puerto Ricans, and $25.6 \%$ of Cubans earned in excess of $\$ 50,000$ ). 
views among the groups. ${ }^{138}$ One might suspect that cleavages among Latinos exist on such volatile issues as civil rights, affirmative action, welfare, and electoral representation.

Different national origin groups have distinctly different assimilation experiences and potentials. While Cubans are the most politically and economically assimilated, Puerto Ricans are the least, with MexicanAmericans somewhere in between.

\section{Language}

There is a good deal of language diversity among Latinos. While many speak Spanish, some do not. ${ }^{139}$ It is evident, however, that restrictions on the speaking of Spanish has a disparate impact on the Latino community ${ }^{140}$ Moreover, Spanish is often classified by Anglo society as a "foreign" language, even though it has long been part of Southwestern culture and was spoken in some states long before they joined the Union.

Though Spanish is spoken by many Latinos, the ability to speak it is not determinative of ethnicity. Spanish was consciously eliminated from the homes of many Latinos striving to assimilate into the Anglo mainstream. ${ }^{141}$ I learned my now-rusty Spanish in school, rather than from my mother. Feeling somewhat ill at ease at Latino gatherings when Spanish is the primary language spoken, I am regularly reminded of this unfortunate aspect of my family history.

The assimilationist ideal would have Latinos learn English and completely lose their Spanish-speaking ability. Many Latinos, however, have maintained Spanish as a part of their culture despite constant attacks. That part of their Latino identity bars complete assimilation into the Anglo mainstream.

Internal divisions exist within national-origin groups as well, such as that between MexicanAmericans and recent Mexican immigrants. See generally David G. GuTIÉRREz, Walls AND Mirrors (1995) (analyzing impact of Mexican immigration on Mexican-American community in U.S. and existence of restrictionist sentiment among some established Mexican-Americans).

138. See Latino Voices, supra note 76 , at 84 (showing that $34.2 \%$ of Cubans surveyed, as compared to $15.4 \%$ of Mexicans and $22.7 \%$ of Puerto Ricans, identified as "conservatives").

139. See SHoRris, supra note 134, at 181-82 ("Third or fourth generation Latinos who live in suburbs of Minneapolis or Atlanta have no more reason to know Spanish than Polish-Americans need to know Polish or German-Americans to know German."); see also Frank Valdes, Under Construction: LatCrit Consciousness, Community and Theory, 85 CALIF. L. Rev. 1087 (1997), 10 LA RAzA LJ. 1 (1997) (analyzing issues of essentialism raised by Spanish language usage among Latinos).

140. See Perea, supra note 54, at 357-60 (analyzing how language regulation may mask national-origin discrimination against Latinos).

141. See, e.g., supra text accompanying notes $44-45$. 


\section{Surnames}

Though having a Spanish surname may impact one's life experiences, it is an imperfect indicator of Latino heritage. A number of Latinos have Anglo surnames, which reflects intermarriage and racial mixture in the United States. ${ }^{142}$ United Nations Ambassador Bill Richardson, a former Congressman from New Mexico who served as chair of the Congressional Hispanic Caucus, is a prominent Latino leader with a Latina mother and Anglo father. ${ }^{143}$ Former football star Jim Plunkett, son of William Gutiérrez Plunkett, a "Mexican with a few German and Irish branches hanging on his side of the family tree," and Carmen Blea, "a Mexican with a trace of Indian blood," is Latino. ${ }^{144}$ Born in Mexico, actor Anthony Quinn is of mixed Irish-Mexican parentage. ${ }^{145}$ Consider also that baseball legend Ted Williams, the last player to bat .400 in a season, had a Mexican mother, even though almost nobody would identify him as a Latino (in no small part because he apparently does not so identify). ${ }^{146}$

In addition, "[e]ven if one could identify with precision which surnames connote Hispanic ethnicity, the question remains whether the name was obtained through marriage or adoption rather than birth. "147 To further complicate matters, some well-known Latinos, such as actor Martin Sheen, born Ramón Estévez, ${ }^{148}$ and singer Vikki Carr, born Florencia Bisenta de Casillas Martínez Cardona, ${ }^{149}$ changed their names

142. See SAMORA \& SIMON, supra note 125 , at 8 ; see also Toro, supra note 71 , at 1255 \& n.216 (noting that Spanish surname is not reliable indicia of Latino identity). For an analysis of some complexities with the retention of maternal surname among Latinas, see Yvonne $M$. Cherena Pacheco, Latino Surnames: Formal and Informal Forces in the United States Affecting the Retention and Use of the Maternal Surname, 18 J. MarShall L. Rev. 1 (1992).

143. See The Hispanic Almanac 201 (Nicolás Kanellos ed., 1994) [hereinafter Hispanic ALMANAC].

144. Jim Plunkett \& Dave Newhouse, The Jm Plunkett Story, 19-20 (1981). Surname complexities create legal complexities as well; see, e.g., Warren v. City of Oakland, 58 F.3d 439, 442-43 (9th Cir. 1995) (addressing Title V1I case in which defendant claimed that he did not know that plaintiff, William Earl Warren 11I, was of Mexican descent).

145. See Hispanic Almanac, supra note 143, at 555.

146. See Toro, supra note 71, at 1258-59 \& n.241.

147. United States v. Changco, I F.3d 837, 841 n.1 (9th Cir.1993), cert. denied, 510 U.S. 1019 (1993).

148. See Juan F. Perea, Ethnicity and Prejudice: Reevaluating "National Origin" Discrimination Under Title VII, 35 WM. \& MARY L. REv. 805, 837-38 (1994). Ironically, demonstrating the phenotypical variance among Latinos, Sheen appeared sufficiently White to portray the famous Confederate General Robert E. Lee in the movie GeTTYSBuRg (Tumer Home Entertainment 1993). See supra text accompanying notes 127-134 (analyzing impact of Latino physical diversity on assimilation experiences).

149. See Hispanic Almanac, supra note 143, at 595. 
to enhance their careers, which highlights the disadvantage of appearing "foreign" in United States society. ${ }^{150}$

The pressures to change rich Spanish names to bland Anglo-Saxon ones have had an impact. Latinos have been deprived of visible Latino public figures. Reflecting the pressures forcing Latinos underground, the changing of the Spanish surname legitimizes the concept that Latinos are not appropriate for polite society and contributes to Latino invisibility. ${ }^{151}$ Even if Latinos knew that some media stars were Latinos, the mere fact that they felt it necessary to change their namesfiguratively to "Whiten" themselves - to succeed, demonstrates the disadvantage of "coming out" as a Latino.

Surname complexities are exacerbated by the wide variety of responses to changing surnames upon marriage. Some mixed Anglo/Latino women with Anglo surnames take their Latino husband's Spanish surname. They may well have identified as Latino before as well as after the marriage, though questions about their identity presumably were posed less frequently after. Some mixed Anglo/Latino women with Spanish surnames do not take their husband's surname ${ }^{152}$ while others do. To complicate matters even more, Anglo women married to Latinos have been counted as "Latinas" by schools seeking to inflate the number of Latino faculty members. ${ }^{153}$

Additional intricacies result with children of mixed Anglo/Latino marriages. Because the common practice in this country is for children to take the surname of their father, reliance on surname as an indicia of a child's Latino-ness is problematic because it places more value on a Latino than a Latina parent. ${ }^{154}$ A mixed child with a Latino father often will have a Spanish surname while one with a Latina mother will not. Surname alone, however, has little to do with whether these persons are "Latino."

Although Spanish surname is not a perfect proxy for Latino identity, it may affect one's life experiences. A Spanish surname may result in differential treatment and discrimination and more subtle affronts, such as treatment as a foreigner.

150. See supra text accompanying notes $80-81$ (discussing treatment of Latino-Americans as foreigners).

151. See Johnson, supra note 10 (analyzing Latino invisibility).

152. See, e.g., Who's Who Among Hispanic Americans 71 (Amy L. Unterburger et al. eds., 2d ed. 1992) (stating that Linda Chávez, whose mother is Anglo, is married to Christopher Gersten).

153. See Olivas, supra note 119 , at 129.

154. See PiATt, supra note 21 , at 43. 


\section{Assimilation Consequences of Latino Diversity}

Put simply, the Latino community is extremely heterogeneous. Latino diversity will only increase with increasing intermarriage between racial groups. The political and economic consequences of this diversity must be addressed in searching for strategies to achieve Latino political and economic participation in United States society.

\section{a. Efforts at Social Change: Political Assimilation}

By hindering consensus building, differences within the Latino community complicate efforts at social change. Internal fissures constrain the ability of Latinos to concentrate focused support behind a meaningful agenda for change. For example, although the Latino leadership has resisted restrictive immigration "reforms," some Latino citizens support such measures. ${ }^{155}$ Activists who attempt to smooth over the differences of opinions on the subject often face charges that the leadership is out of touch with the rank-and-file. ${ }^{156}$ To mold a consensus for change tailored to the Latino community, recognition of the diversity within the community is a critical first step.

Four important components of Latino identity, which may serve as the basis for Latino coalition building, are family, ethnicity, religion, and the Spanish language. ${ }^{157}$ These characteristics all contribute to the aura among Anglos that Latinos are "foreign," and may serve as rallying points around which unity can be built. ${ }^{158}$ These common characteristics may well be the focal point for efforts at political assimilation. ${ }^{159}$ To achieve change within the political process, ${ }^{160}$

155. See generally GUTḰrREz, supra note 137 (analyzing historically significant restrictionist sentiment in Mexican-American community). This is suggested by the support by a significant number, though still a distinct minority, of Latino citizens for California's Proposition 187. See Johnson, supra note 15 , at $658-59$ (presenting exit poll data on vote).

156. See Peter Skerry, Mexican-Americans: The Ambivalent Minority 217-49 (1993).

157. See HAYES-BAUTISTA ET AL., supra note 77, at 34 (summarizing quantitative data).

158. See Johnson, supra note 10.

159. Cf. Kimberle Williams Crenshaw, Race, Reform, and Retrenchment: Transformation and Legitimation in Antidiscrimination Law, 101 HARV. L. REv. 1331, 1336 (1988) (contending that "the Black community must develop and maintain a distinct political consciousness . . . . History has shown that the most valuable political asset of the Black community has been its ability to assert a collective identity and to name its collective political reality.").

160. I agree with George Martínez and others that litigation alone cannot achieve fundamental social change for Latinos. See George A. Martínez, Legal Indeterminacy, Judicial Discretion and the Mexican-American Litigation Experience: 1930-1980, 27 U.C. DAvIS L. Rev. 555 (1994) (documenting failure of litigation to change status of Mexican-Americans in United States). See generally Richard Delgado \& Jean Stefancic, Failed Revolutions (1994) (analyzing limits on achieving social change through law). 
coalitions must be built within the Latino community as well as with other subordinated groups. ${ }^{161}$

\section{b. Affirmative Action and Economic Assimilation}

Latino diversity causes practical problems regarding affirmative action and related programs that must be addressed. As one Supreme Court Justice recognized, one federal agency was required "to trace an applicant's family history to 1492 to conclude that the applicant was 'Hispanic' for purposes of a minority tax certificate policy."162 Assuming race may be considered as a factor in future governmental programs, ${ }^{163}$ other questions are posed. For example, should differences in the Latino community affect eligibility for affirmative action programs? Specifically, should immigrants from Latin America-as opposed to Latino citizens-be eligible for affirmative action? These and related questions raise potentially explosive issues within the Latino community. However, the remedial arguments for affirmative action for Mexican-Americans whose families have lived in this country for generations at first glance may appear stronger than for recent immigrants from Latin America. ${ }^{164}$ In a similar vein, inequities arguably result when Latino immigrants are eligible for affirmative action programs designed to remedy pervasive systemic discrimination against AfricanAmericans. ${ }^{165}$ Although increasing diversity, immigrant eligibility may not provide relief for past discrimination. ${ }^{166}$ Immigrants, even if racial

161. See Johnson, supra note 52, at 66-67 (articulating need for multiracial coalitions); Charles R. Lawrence III, Foreword: Race, Multiculturalism, and the Jurisprudence of Transformation, 47 STAN. L. REv. 819, 828-47 (1995) (analyzing need for, as well as obstacles to, building multiracial coalitions).

162. Metro Broad., Inc. v. Fed. Communications Comm'n, 497 U.S. 547, 633 n.1 (1990) (Kennedy, J., dissenting) (citation omitted).

163. Questions about the implementation of affirmative action may become moot if the Supreme Court, as at least one court of appeals has, finds affirmative action to be unconstitutional. See Hopwood v. Texas, 84 F.3d 720 (5th Cir.), cert. denied sub nom. Thurgood Marshall Legal Society v. Hopwood, 116 S. Ct. 2580, and cert. denied sub nom. Texas v. Hopwood, 116 S. Ct. 2581 (1996). In any event, political forces may limit, if not abolish, affirmative action. See Coalition for Economic Equity v. Wilson, 110 F.3d 1431 (9th Cir.), cert. denied, 66 U.S.L.W. 3324 (U.S. 1997); William H. Honan, Admissions Change Will Alter Elite Campuses, Experts Say, N.Y. TıMEs, July 22, 1995, § 1, at 7 (reporting that Board of Regents of University of California passed resolution prohibiting use of race in student admissions).

164. See Brest \& Oshige, supra note 29 , at 890 (suggesting that different Latino national-origin groups deserve different treatment in affirmative action programs for education).

165. See, e.g., Brimelow, supra note 72, at 218-19; RichaRd D. KAHLENBERG, The RemedY 74-80, 114 (1996).

I66. See Kahlenberg, supra note 165 , at 139 (raising issues surrounding immigrant eligibility for affirmative action); Peter H. Schuck, Alien Rumination, 105 YALE L.J. 1963, 2000-04 (I996) (book review); see also Michael Lind, The Next American Nation 116, 131 (1995) (suggesting that 
minorities, have not descended from persons subject to centuries of racial subordination in the United States. Whether that fact should be determinative, or whether other factors militate in favor of inclusion of immigrants in affirmative action programs, is an open question. The issue becomes even more difficult, however, because immigrants of color may be subject to discrimination once in this country. ${ }^{167}$

Due to Latino diversity, some, most prominently Peter Brimelow in the much-publicized anti-immigrant polemic Alien Nation, ${ }^{168}$ claim that community leaders have constructed a fake identity for purposes of securing affirmative action and other benefits. This characterization misses the point that Latinos share common interests, political and otherwise, which deserve group treatment. These critics ignore the fact that Latinos as a group, even though diverse, are not integrated into the political and economic mainstream. Put differently, dominant society classifies Latinos as a distinct group of foreigners. Affirmative action is designed to remedy the negative group treatment of Latinos by facilitating economic integration and assimilation.

$$
* * * *
$$

In sum, care must be taken not to essentialize or simplify the Latino experience. ${ }^{169}$ Latinos are an exceedingly diverse group. Latino heterogeneity has contributed to a diversity of assimilation experiences and reveals that certain community members have different assimilation potentials. This diversity need not be taken to mean that all is lost. Commonalities of interests and opportunities for change can and should be explored. Resisting Anglo cultural domination, Latinos will continue to demand political and economic integration.

\footnotetext{
"Hispanics" and immigrants should not be eligible for affirmative action); Frank H. Wu, The Limits of Borders: A Moderate Proposal for Immigration Reform, 7 STAN. L. \& POL'Y REV. 35, $51-54$ (1996) (analyzing complex relationsbip between immigration and affirmative action debates in modern United States). But cf. Christopher F. EdLey, JR., Not All Black aND White 174 (1996) (contending that, because of racism against Blacks in United States, Black immigrants should be eligible for affirmative action).

167. See Charles R. Lawrence III \& Mari J. Matsuda, We Won't Go Back 262-64 (1997).

168. BRIMELOW, supra note 72; see SKERRY, supra note 156, at 308-09 (criticizing imprecision of term "Hispanic"). For criticism of the book as an attack on not only immigrants but on all Latinos, see Kevin R. Johnson, Fear of an "Alien Nation": Race, Immigration, and Immigrants, 7 STAN. L. \& POL'Y REV. 111 (1996).

169. Cf. Angela P. Harris, Race and Essentialism in Feminist Legal Theory, 42 StaN. L. Rev. 581 (1990) (criticizing gender essentialism in feminist legal theory that erases experiences of women of color).
} 


\section{Where Do Anglo/Latinos Belong?}

This section analyzes the place of persons of Anglo/Latino backgrounds in U.S. society in a highly charged era of identity politics. Mixed Latinos face identity issues similar but different from those facing persons of mixed Black/White origin. In analyzing the identity choice for this group of Latinos, this section considers their prospects for full assimilation into the Anglo mainstream.

\section{The Generic Mixed-Race "Problem"}

The racial demographics of the United States have shifted dramatically over the last third of the twentieth century, marked by a great increase in the proportion of Latinos and Asian-Americans comprising the total population..$^{170}$ Most fundamentally, race relations in the United States are far more complex today than a century ago. As Deborah Ramírez succinctly put it, "[i]t's not just Black and White anymore."171 Due to intermarriage, ${ }^{172}$ more multiracial people live in the United States than ever before. ${ }^{173}$ These changes, without doubt, require a broad focus on all racial minorities in analyzimg race relations in this country. ${ }^{174}$

The increasing number of multiracial people in the United States has generated legal difficulties because " $[\mathrm{t}] \mathrm{he}$ American legal system today lacks intermediate or 'mixed race' classifications."175 This country has a long tradition of simply ignoring the existence of mixedrace people. The so-called "one drop rule" resulted in the classification as "African-American" of all persons who possessed "one drop"

170. See Deborah Ramírez, Multicultural Empowerment: It's Not Just Black and White Anymore, 47 STAN. L. REv. 957, 960-62 (1995) (reviewing demographic data showing that people of color increased from 10 to 25 percent of the U.S. population from 1960 to 1990).

171. Id. at 957.

172. See Schuck, supra note 166, at 1999 (summarizing statistical data showing that intermarriage rates are increasing dramatically among various racial groups). Intermarriage rates for Mexican-Americans and Anglos vary regionally, with the border region having much lower rates than the interior. See MARTínez, supra note 43, at 325 n.5.

173. See Ramírez, supra note 170, at $964-69$ (discussing practical issues raised by increasing numbers of multiracial persons); see also Alex M. Johnson, Destabilizing Racial Classifications Based on Insights Gleaned from Trademark Law, 84 CALIF. L. REv. 887 (1996) (analyzing significance of multiracial status of African-Americans and contending that multiracial identity may destabilize system of racial categorization in United States). For a summary of issues implicated by the growth in the multiracial population, see Bijan Gilanshah, Multiracial Minorities: Erasing the Color Line, 12 LAW \& INEQ. J. 183 (1993).

174. See Richard Delgado, Rodrigo's Fifteenth Chronicle: Racial Mixture, Latino-Critical Scholarship, and the Black-White Binary, 75 TEX. L. REv. 1181 (1997).

175. Neil Gotanda, A Critique of "Our Constitution is Color-Blind," 44 STAN. L. REv. 1, 25 (1991); see Karst, supra note 102, at 299-305. 
of "Black" blood. ${ }^{176}$ Though making racial classifications administratively convenient for discriminatory purposes, this rule classified as "Black" an entire array of persons who varied greatly in terms of parentage and physical appearance.

When the naturalization laws required that a noncitizen be "White" or of African descent to naturalize, the courts had to grapple with how to classify persons of mixed heritage. In facing the question whether a noncitizen with an English father and a mother who was one-half Chinese and one-half Japanese was "White," one court emphasized that "[a] person, one-half white and one-half of some other race, belongs to neither of those races, but is literally a half-breed."177 Adopting this type of reasoning, the courts consistently found mixed-race persons not to be "White" and therefore ineligible for naturalization. ${ }^{178}$

As this suggests, mixed-race people have been marginalized when not ignored. ${ }^{179}$ The derogatory reference to "half-breeds" exemplifies the marginalization. ${ }^{180}$ Academic theories have supported this treatment. For example, at the end of the nineteenth century, scientists believed that the child of Black and White parents was inferior, ${ }^{181}$ a sentiment that still

176. See Stonequist, supra note 7, at 24; Lawrence Wright, One Drop of Blood, New YoRKER, July 25, 1994, at 46; see, e.g., Plessy v. Ferguson, 163 U.S. 537, 541 (1896) (rejecting equal protection claim of person of seven-eighths White and one-eighth Black blood). For the argument that the "one drop" rule helped build African-American solidarity in the fight against racial injustice, see Christine B. Hickman, The Devil and the One Drop Rule: Racial Categories, African Americans, and the U.S. Census, 95 Mich. L. REv. 1161 (1997).

177. See In re Knight, 171 F. 299, 301 (E.D.N.Y. 1909) (emphasis added); see HANEY LóPEz, supra note 92, at 61 (analyzing In re Knight); see also George W. Gold, The Racial Prerequisite in the Naturalization Law, 15 B.U. L. REv. 462, 494-96 (1935) (summarizing caselaw analyzing whether "half-breeds" were White for purposes of naturalization).

178. See Kevin R. Johnson, Racial Restrictions on Naturalization: The Recurring Intersection of Race and Gender in Immigration and Citizenship Law, 11 BERKELEY WOMEN's L.J. 142, 151 (1996) (reviewing IAN HANEY López, White BY LAW (1996)). There is at least one important exception to this general rule. Due to obligations under treaties with Mexico, the one reported decision that addressed the "mixed race" question for Mexican nationals (by definition of mixed race) concluded that they were "White" and therefore eligible for naturalization. See In re Rodriguez, 81 F. 337 (W.D. Tex. 1897); see also George A. Martínez, Mexican-Americans and Whiteness, 2 Harv. LATINO L. REV. (forthcoming 1997) (analyzing importance of Rodriguez in analyzing race as social and political construct).

179. See Herbert Hovenkamp, Social Science and Segregation Before Brown, 1985 DukE L.J. 624,670 ("The mulatto's plight was exacerbated because he was disowned by both races and regarded as a rootless, useless half-breed.").

180. See Robert Laurence, A Memorandum to the Class, 46 ARK. L. REv. 1, 2 n.3 (1993) (collecting popular slurs, including "half-breed," directed at Indians).

181. See Hovenkamp, supra note 179, at 657 ("In the scientific view of the day a racially mixed couple... [was] likely to produce inferior offspring that would be a lifetime burden on society and were guaranteed to weaken and contaminate both the white and the black races."). This illustrates some of the shortcomings of integrating science into legal decision-making. Cf. Holly Doremus, 
survives in some quarters. ${ }^{182}$ The mixed heritage of persons of Mexican ancestry brought forth similar responses. In the words of T.J. Farnham in the mid-1800s:

No one acquainted with the indolent, mixed race of California, will ever believe that they will populate, much less, for any length of time, govern the country. The law of Nature which curses the mulatto here with a constitution less robust than that of either race from which he sprang, lays a similar penalty upon the mingling of the Indian and white races in California and Mexico. They inust fade away .... ${ }^{183}$

Though animosity toward mixed-race people may be on the wane, "[ $t]$ he rich diversity literally embodied by Multiracial people [has been] hidden from view, hidden from discourse, hidden from recognition and thus, invisible."184 Lacking intermediate classifications, the law constructs a neat, dichotomous legal world. ${ }^{185}$ In the 1990 s, the Bureau of

Listing Decisions under the Endangered Species Act: Why Better Science Isn't Always Better Policy, 75 WASH. U. LQ. (forthcoming 1997) (contending that science alone cannot govern administration of complex environmental statute requiring scientific input because of, among other things, subjcctivity inherent in scientific inquiry).

182. Cf. Richard J. Herrnstein \& Charles Murray, The Bell Curve (1994) (contending that race and intelligence are linked). Consider Greg Williams' reaction to watching on television a Ku Klux Klan leader decrying the Supreme Court's decision in Brown v. Board of Educ., 347 U.S. 483 (1954):

He claimed that the Supreme Court was encouraging "race-mixing" and the only result would be the "bestial mongrel mulatto, the dreg of human society." [H]is nasal repetition of "mongrel mulatto" finally hit me like a thunderbolt. He was talking about me. I was the

Klan's worst nightmare. I was what the violence directed against integration was all about. I was what they hated and wanted to destroy.

WILLIAMS, supra note 23 , at 91 .

183. T.J. Farnham, Life, Adventures and Travel in Californin 413 (1840). For analysis of Farnham's racialization of Mexicans, see Haney Lopez, supra note 103, at 29-37; see also Guadalupe T. Luna, "Agricultural Underdogs" and International Agreements: The Legal Context of Agricultural Workers within the Rural Economy, 26 N.M. L. REv. 9, 9 (1996) ("The Mexican 'peon' (Indian or mixed-breed) is a poverty-stricken, ignorant, primitive creature, with strong muscles and with just enough brains to obey orders and produce profits under competent direction." (quoting Lothrop Stoddard, Re-Forging AMerica: The Story of Our Nationhood 214 (1927))); Perea, supra note 45 , at 976-77 (collecting disparaging comments during period about Mexicans as racial "mongrels").

184. Julie C. Lythcott-Haims, Note, Where Do Mixed Babies Belong? Racial Classifications in America and Its Implications for Transracial Adoption, 29 HARV. C.R.-C.L. L. REv. 531,540 (1994); see Ruth Colker, Bi: Race, Sexual Orientation, Gender, and Disability, 56 OHIo ST. L.J. 1, 12 (1995) (arguing that governmental non-recognition of "multiracial" category renders multiracial people invisible).

185. See Colker, supra note 184, at 64-67 (analyzing failure to account for mixed-race persons and efforts to use two categories for gender (man or woman), sexual orientation (homosexual or heterosexual), and disability (disabled or not)); see also Kenneth E. Payson, Comment, Check the 
the Census stirred controversy by considering the addition of a multi-racial category to its racial classification scheme. ${ }^{186}$ Some African-American leaders expressed concern that mixed-race people who previously identified as Black might begin to identify themselves as "multiracial," thereby diluting the strength of Blacks in electoral representation, affirmative action, and federal contracting programs. ${ }^{187}$

The number of multiracial peoples undoubtedly will increase in the future. How this may impact political and racial subordination in this country is far from clear. By blurring the lines between racial categories, multiracial people may destabilize the racial status quo. In light of this nation's racial history, however, optimism is far from warranted.

One might hope that, because of the rate of intermarriage and the growing multiracial population, ${ }^{188}$ the number of multiracial people will build empathy among members of dominant society. Many people in the future will be multiracial or familiar with, and perhaps even related to, racial minorities or multiracial people. ${ }^{189}$ Interracial marriages, however, have occurred for centuries without a radical racial transformation. This suggests the need for circumspection about the transformative potential of intermarriage.

Box: Reconsidering Directive No. 15 and the Classification of Mixed-Race People, 84 CALIF. L. REv. 1233 (1996) (discussing classification problems for mixed-race persons).

186. See Colker, supra note 184, at 14-15; Ramírez, supra note 170, at 968-69; see also 62 Fed. Reg. 36,874 (July 9, 1997) (requesting comments on report recommending against creating new multiracial category for Census but permitting persons to identify as more than one race).

Multiracialism received heightened media attention when professional golfing sensation Tiger Woods claimed not to be African-American, as many assumed based on his physical appearance, but to be "Cablinasian," a mixture of Caucasian, Black, Indian, and Asian. See Michael A. Fletcher, Woods Puts Personal Focus on Mixed-Race Identity, WASH. Post, Apr. 23, I997, at A1. Whatever his actual ancestry, Woods suffered personal attacks as a child and later as an adult because of the perception that he was African-American. See Mike Aitken, Woods Savours Troon Test, Scotsman, May 2, 1997, at 35 (telling of racism directed at Woods as child); Larry Dorman, The 6lst Masters, N.Y. TIMES, Apr. 14, I997, at $\mathrm{Cl}$ (describing hate mail directed at Woods as professional golfer).

187. See Ramírez, supra note 170, at 968 . For a description of the heated political battle over creating a multiracial category, see Linda Mathews, More Than Identity Rides on New Racial Category, N.Y. TimEs, July 6, 1996, at 1 .

188. See GlAZER, supra note 62, at 129-30 (expressing hope for assimilation of AsianAmericans and Latinos due to relatively high rates of intermarriage). Compare Jim Chen, Unloving, 80 lowA L. REv. 145 (1994) (embracing image of U.S. as "Creole Republic" in which these demographic trends promote racial harmony), with Peter Kwan, Unconvincing, 81 IowA L. REv. I557 (1996) (contending that such hopes are misplaced).

189. Cf. James W. Gordon, Did the First Justice Harlan Have a Black Brother?, 15 W. N. ENG. L. REv. 159 (1993) (contending that Justice Harlan, author of dissent in Plessy v. Ferguson, 163 U.S. 537, 552 (1896) (Harlan, J., dissenting), which many view as endorsing color blindness, had halfbrother who was half-Black and suggesting that this relationship may have influenced Justice Harlan's thinking on issues of race). 


\section{Identity Ambiguity for Anglo/Latinos}

Mexican-Americans, and Latinos more generally, represent diverse mixtures of races. ${ }^{190}$ Mexican-Americans are the product of a lengthy history of intermixture of Spanish, indigenous, African, and other peoples. In sharp contrast to the clear, unequivocal racial categorization schemes constructed by U.S. law and society, ${ }^{191}$ "Latinos, and especially Mexican-Americans, have been conditioned by their history ... to accept racial ambiguity and mixture as "normal." 192 In contrast to the dim view of racial mixture taken by Anglo colonizers, Mexican philosophers considered the mixture as positive, a raza cosmica ("cosmic race"). ${ }^{193}$ Similar to the boundaries between the races, Americans consider the U.S.-Mexico border to be a physically fixed location while Mexicans refer to la frontera, a concept similar to the indefiniteness of the "frontier" in the American imagination. ${ }^{194}$ Though Latinos may readily accept racial ambiguity, United States society has imposed rigid racial classifications. This affects the specific identity issues for persons of mixed Latino heritage.

Animus toward Anglo/Latinos appears less of a problem than for other mixed-race persons. ${ }^{195}$ This is consistent with the long history of intermarriage between Anglos and persons of Mexican ancestry in the Southwest. For example, when my Uncle Brown-eyes married his Mexican-American wife, Rosie, in the 1940s, a few Anglo eyebrows

190. See supra text accompanying notes 127-134 (analyzing Latino racial diversity).

191. See supra text accompanying note 28 (noting psychological need for racial categorization).

192. Carlos A. Fernández, La Raza and the Melting Pot: A Comparative Look at Multiethnicity, in Racially Mixed People in America, supra note 19, at 126, 139; see also Adrienne D. Davis, Identity Notes Part One: Playing in the Light, 45 AM. U. L. REv. 695, $697-99$ (1996) (describing African-American author's experience with racial fluidity in modern Nicaragua). This racial mixture is referred to in Spanish as mestizaje. See Margaret E. Montoya, Academic Mestizaje: Re/Producing Teaching, Scholarship, \& Service on Behalf of Latino Communities, 2 HaRv. Latino L. REv. (at 6 of draft) (forthcoming 1997) (describing genesis of term); see generally JULIAN SAMORA, Mestizaje: The Formation of Chicanos (1996) (discussing generally concept of mestizaje among Chicanos, including racial intermixture in his family).

193. See Martínez, supra note 178, at $33 \mathrm{n} .123$ (discussing Mexican philosopher José Vasconcelos' prediction of emergence of raza cosmica (citing PATRICK ROMANELL, THE MAKING OF THE MEXICAN MIND 133 (1971)). Of course, this is not to ignore the racial stratification in Latin America, which has long been a problem. See generally Magnus Mörner, RaCE MiXTURE IN THE HistORY OF LATIN AMERICA (1967).

194. See Rodríguez, supra note 97 , at 84-85.

195. This implies the existence of a loose racial hierarchy. See Johnson, supra note 178 , at 150 51, 165-66 (recognizing racial hierarchy); Natsu Taylor Saito, Alien and Non-Alien Alike: Citizenship, "Foreignness" and Racial Hierarchy in American Law, 71 OR. L REv. (forthcoming 1997) (analyzing importance of racial hierarchy in maintaining subordination). But cf. Chew, supra note 80, at $87-89$ (arguing that "race to the bottom" by different minority groups claiming greater disadvantage is "divisive" and "not construetive"). 
probably were raised. The reaction in no way approximates that which would have resulted if he had married an African-American woman.

In effect, some mixed-background Latinos may be treated as "White" by the rest of society. As others have characterized the phenomenon for African-Americans, they may "pass" as White. ${ }^{196}$ However, the ability to "pass" is not without costs. Professor Cheryl Harris offered the sad example of her grandmother who suffered great pain living two lives, "passing" in order to work in the day as "White," only to live as Black at night. ${ }^{197}$

Some Latinos, as my mother and grandmother did, attempt to "pass" as Spanish in the United States. ${ }^{198}$ In the Southwest, to be stigmatized by Anglos as "Mexican" places one at a distinct disadvantage in certain circumstances. A Latino who attempts to live as Anglo suffers in other ways, however. My mother's assimilation ordeals reveal the psychological and related costs. My experiences, though far less severe, reveal the pain suffered by mixed-race persons thought to be White.

In essence, the capability of "passing" is a double-edged sword. Adrian Piper eloquently captures the pain she suffered as an AfricanAmerican who might have been able but declined to "pass" as White. ${ }^{199}$ Some Blacks demanded proof of her Blackness; others subjected her to White slurs. ${ }^{200}$ At the same time, some Whites in academia have suggested that she declared a Black identity to reap affirmative action benefits. ${ }^{201}$ This Catch-22 greatly affects the shaping of one's identity as well as life experiences. Over my lifetime, I have experienced both sorts of challenges to my identity. ${ }^{202}$ Some Latinos express curiosity about

196. See SCALES-TRENT, supra note 4, at 95-98 (discussing great uncle who left family to pass as White); Patricia J. Williams, The Alchemy of Race and Rights 223 (1991) (relating story of relative who left family to pass and marry a White man).

197. See Harris, supra note 117, at 1710-12; see also STONEQuist, supra note 7, at 189-90, 193 99 (mentioning psychological problems and mental conflicts resulting from "passing" and being mistaken for another race).

198. See Guillermo Lux \& Maurilio E. Vigil, Return to Aztlán: The Chicano Rediscovers His Indian Past, in AzTLÁN 97-98 (Rudolfo A. Anaya \& Francisco A. Lomelí eds., 1989); see also P1ATT, supra note 21, at 157 (offering his experiences about Mexican-Americans attempting to pass as Spanish in New Mexico); SÁNCHez, supra note 68, at 264 (describing Chicano leaders critical of Chicanos who claimed to be Spanish). Of course, matters are complicated in some places such as northern New Mexico where centuries ago, Spaniards in fact settled. See generally GEORGE I Sánchez, Forgotten People (1940 rev. ed. 1967). But cf. Oboler, supra note 8, at 25-26 (contending that "Spanish-Americans" in New Mexico have a "fantasy heritage"" of racial purity that is used to justify retention of power and status).

199. See Adrian Piper, Passing for White, Passing for Black, 58 Tr ansition 4 (1992).

200. See id. at 6-7.

201. See id. at $4,8-9$.

202. 1 offer greater detail of my experiences in this regard in JoHNSON, supra note 115 . 
my background, where I come from, my commitment to Latino issues, and Spanish speaking skills, probing whether I am only a "check-thebox" ${ }^{203}$ Latino in pursuit of the benefits of affirmative action. Whites with similar concerns scrutinize my identity as a Latino. ${ }^{204}$ Life under a microscope at times is disorienting, uncomfortable, and burdensome.

Piper also offers insights into another layer of complexity. She resented some family members with fair complexions who sealed themselves off from the rest of the family as part of their attempt to pass as White. ${ }^{205}$ Though able to achieve higher status, they left their Black family behind, with all the emotional turmoil and sadness that resulted. As has been my experience as illustrated in the story with which I began this article, minorities who "look White" hear some horrible things about what Whites think about their kinship group. Moreover, attempts to "pass," as my mother and grandmother harshly learned, are not always successful. ${ }^{206}$ Not all persons recover from the pain of rejection and sting of defeat. Like Piper, I at times resent yet understand efforts to appear White (and gain its privileges) ${ }^{207}$ through adoption of a phantom "Spanish" identity.

Whatever the assimilation route taken by Latinos with "White" appearances, it is clear that their life experiences and identities are shaped by the fact that to be White is to be at the top of the social hierarchy in the United States. Those who embrace their minority identity suffer a set of harms different than those who reject it. But, importantly, costsfrom which Whites generally are immune-are imposed on both Latino sub-groups. The root cause of the harm is the racial subordination that permeates U.S. society.

Mixed-background Latinos today may feel as if they fail to fit into either Anglo or Latino society and may be in a unique position to suffer subtle insults and other challenges to their identity. ${ }^{208}$ A modern, often unstated, fear not infrequently arises that multiracial persons will selfidentify to maximize their eligibility for benefits that exist under

203. See Toro, supra note 71 , at 1253 (discussing concept of "box checking").

204. See infra text accompanying notes 231-232 (offering experiences from academic life illustrating this).

205. See Piper, supra note 199, at 13.

206. See supra text accompanying notes 31-51 (analyzing some of those experiences).

207. See generally Stephanie Wildman, Privilege Revealed (1996) (analyzing hidden privilege attached to Whiteness).

208. For a description of such a case, see MARTínez, supra note 43, at 267-70 (describing difficulties of Carlos Strumm, half German, half Mexican, who grew up along border), 296-97 (describing problems of son of Mexican and Anglo parents growing up along border). 
modern racial classification schemes. ${ }^{209}$ A mixed Latino/Anglo person, so the theory goes, may classify as Latino to gain affirmative action benefits. A perhaps less common example is when a person of mixed Asian and African-American heritage identifies herself as Black as opposed to Asian, ${ }^{210}$ because of quotas that elite educational institutions place on the admission of Asian-American students. ${ }^{211}$ These situations differ from outright fraud, such as when an Anglo claims to be Latino or Black. ${ }^{212}$

No definite answer exists to how a person should classify herself when given an either/or choice, rather than one that better reflects the complexities of modern multiracial America. Due to the absence of rules, identity choice by necessity is somewhat arbitrary and subjective. As Linda Chávez, the daughter of a Latino father and a British-Irish mother, explained, she had "very little identification with my mother's background. I always thought of myself as Latina despite the fact that I didn't speak Spanish." "213 Some mixed Latinos classify themselves as White, others as Latino. Some identify as Latino at a point in life, perhaps in response to affirmative action considerations, but not at other

209. See supra text accompanying notes $118-119$ (discussing affirmative action and racial identity).

210. See Ramírez, supra note 170, at 967-68; see generally Christopher A. Ford, Administering Identity: The Determination of "Race" in Race-Conscious Law, 82 CALIF. L. Rev. 1231, 1239-62 (1994) (analyzing difficulties in determining individual's race for race-conscious programs).

211. See Grace W. Tsuang, Note, Assuring Equal Access of Asian Americans to Highly Selective Universities, 98 YALE LJ. 659, 660-61 (1989) (observing that University of California at Berkeley, Stanford, and Brown do not consider Asians in affirmative action programs for student admissions).

212. See Luther Wright, Jr., Comment, Who's Black, Who's White, and Who Cares: Reconceptualizing the United States's Definition of Race and Racial Classifications, 48 VAND. L. REV. $513,515-16$ (1995) (describing fraud by Malone brothers who claimed to be Black in successfully seeking firefighter jobs); see also Toro, supra note 71, at 1254-55 (discussing case of White who changed his name to Roberto Eduardo León, claimed to be Hispanic, and asked employer to change racial designation from White to Hispanic).

213. Lee May, U.S. English Chief: Controversy Spoken Here, L.A. Times, Aug. 6, 1987, pt. 5 at 1 (quoting Chávez); see Don Kowet, She Would Bring Back Melting Pot, Wash. Times, Jan. 9, 1992, at El (noting that Chávez said her father descended from Spanish settlers of New Mexico).

Another example of this arbitrariness is the classification of prominent federal judge Harold Medina, whose father was a Mexican immigrant and mother an Anglo. See HawtHoRne Daniel, JUDGE MEDINA 11-12 (1952). Though Medina is listed in the Hispanic Almanac, supra note 143, at 242-43, one book claims that Reynaldo Garza was the first Mexican-American federal judge, even though appointed over a decade after Medina, because "[p]olitical figures... were unaware of [Medina's] Mexican roots" at the time of his confirmation. LoUise ANN FisCH, ALl RISE, Reynaldo G. Garza, The First Mexican American Federal Judoe 177 n.l (1996). 
times. Without a clear classification rule, there is no clearly acceptable course of conduct. ${ }^{214}$

The ambiguity of racial classifications for mixed Latinos can be seen in the controversy involving Maria Hylton, a law professor with a White Australian and a Black Cuban parent, who was being considered for a faculty position at Northwestern University School of Law. ${ }^{215}$ She identified herself as Black, not as a Latina as others of similar backgrounds have. ${ }^{216}$ But was Hylton Black? An African-American professor at Northwestern claimed that, because the candidate's background differed from that of many African-Americans in the United States, Hylton was not. ${ }^{217}$

Because of the increasing prevalence of classification conundrums like these, increasing academic scrutiny has focused on the experiences of multiracial peoples, ${ }^{218}$ and a field of Critical "Mixed Race" Theory has developed. ${ }^{219}$ Although African-American legal scholars of White and African-American parents have written books documenting their journeys, ${ }^{220}$ there has been surprisingly little analysis of the mixed Anglo/Latino experience. This is true despite the fact that racially diverse mixtures almost inevitably result in a diversity of experiences.

214. For an analysis of the classification conundrums facing Piri 'Thomas' family of mixed Indian, African, and European descendants as described in PIRI Thomas, Down These Mean STREets (1967), see Haney L6pez, supra note 103, at 40-44.

215. See Irene Sege, Not Black Enough?, Boston Globe, Feb. 9, 1995, at 63 (discussing controversy over appointment of Professor Maria Hylton); see also CLINT BoLick, THE AfFIRMATIVE ACTION FRAUD 18 (1996) (describing incident as part of general attack on affirmativc action).

216. See Gloria Sandrino-Glasser, Los Confundidos: De-Conflating Latinos/as' Racc and Ethnicity, unpublished manuscript, at 24-33 (discussing history of Cuban migration to United States from perspective of Black Cuban-American and analyzing the conflation of race and national origin).

217. For responses to the claim that Maria Hylton was not Black, see Leonard M. Baynes, Who is Black Enough for You? The Stories of One Black Man and His Family's Pursuit of the American Dream, 11 GEo. IMMIG. L.J. 97 (1996); Leonard M. Baynes, Who is Black Enough for You? Analysis of Northwestern University's Struggle Over Minority Faculty Hiring, 2 MicH. J. RACE \& L. 205 (1997).

218. See generally PAUL R. SPICKARD, MIXED BLOOD (1989) (focusing on intermarriage between White persons and Japanese-Americans, Jewish-Americans, and African-Americans); RACIAlly MiXed PeOple IN America, supra note 19 (compilation of chapters on mixed-race persons generally, including some focusing on mixed-race Latinos); NAOMI ZACK, RACE AND MiXed RACE (1993) (analyzing expcrience of mixed Black-White persons).

219. See Lewis R. Gordon, Critical "Mixed Race," 1 Soc. IDENTITIEs 38I, 39I (1995) (acknowledging that "biracial people have the unique experience of living the racial realitics of more than one group in the course of their innermost private lives"). For an analysis of the burgeoning literature in Critical Multiracial Studies, see Jean Stefancic, Multiracialism: A Bibliographic Essay and Critique in Memory of Trina Grillo, 81 MINN. L. REv. 1521 (1997).

220. See SCALEs-Trent, supra note 4; Williams, supra note 23. 
Consider the backgrounds of a few Latino law professors: a Latina with a "Cuban Black" father and a mother who is the "daughter of Italian immigrants;" a "Mexican, Irish, Jewish, Woman, Heterosexual, Aunt, Law Professor, Californian, Bostonian, Tusconian, middle child, professional" grappling with multiple identities; ${ }^{.22}$ a Latina with a Mexican immigrant mother and a Canadian citizen father; ${ }^{223}$ one whose "father was Irish, . . . mother . . . Mexican;"224 a Latino who is the son of a "fourth-generation Irish father" and a "Salvadoran immigrant mother;"225 another Latino whose mother was "Mexican-American, his father Anglo-American" from New Mexico; ${ }^{226}$ and a Latina "born in Cuba [who] grew up in Puerto Rico."227

\section{One Identity Choice}

Mixed Anglo/Latinos stand at a peculiar intersection of modern American life. Those who appear Anglo may avoid the overt discrimination often directed at people of color generally and dark-skinned Latinos in particular. For that reason, their paths to assimilation might prove easier than for others. This, of course, may even be true to some extent for Latinos with lighter skin who do not "fit" the classic Latino stereotype. They will have different life experiences than persons who fit the stereotype or have other indicia of "foreignness." 228

I have known several persons, like myself, of mixed Anglo/Mexican-Americans who chose different paths in building a socially-recognized identity. In ways reminiscent of my mother, some

221. Trina Grillo, Anti-Essentialism and Intersectionality: Tools to Dismantle the Master's House, 10 BERKELEY WOMEN'S L.J. 16, 22-23 (1995).

222. Leslie G. Espinoza, Multi-Identity: Community and Culture, 2 VA. J. Soc. PoL'y L. 23, 26 (1994).

223. Yxta Maya Murray, An Essay on the Latino-American Crisis of Citizenship, 31 U.C. DAv1s

L. REv. (at 15 of draft) (forthcoming 1997).

224. Rachel F. Moran, Full Circle, in Critical RaCe Feminism: A Reader 113, 113 (Adrien Katherine Wing ed., 1997).

225. Haney López, supra note 103 , at 10.

226. Terry Farish, CHOICE Interviews: Bill Piatt, CHOICE, Feb. 1994, at 898, 899.

To complicate matters further, Latinos of parents of different national-origin groups may have an entire set of issues with which to grapple. See Enid Trucios-Haynes, The Legacy of Racially Restrictive Immigration Laws and Policies and the Construction of the American National Identity, 76 OR. L. Rev. (forthcoming 1997) (describing Latina with Puerto Rican mother and father of Panamanian descent).

227. Berta Esperanza Hernández-Truyol, Building Bridges: Bringing International Human Rights Home, 9 La Raza L.J. 69, 70 (1996).

228. See supra text accompanying notes 80-81 (analyzing this phenomenon). 
denied their heritage. ${ }^{229}$ In contrast, for some Anglo/Latinos, their mixed heritage is a non-issue. I recently met a young professor with a Spanish surname. My mixed background came up in conversation. He matter-of-factly said that he had a similar background, though reversed, with a Mexican-American father and an Anglo mother. In contrast to my experience, his surname and dark complexion diminished the questioning of his identity. ${ }^{230}$ The myriad responses to a single social phenomenon demonstrates how racial identities are socially, not biologically, constructed, and just how complex identity formation can be.

The identity complexities in my life suggest some of the issues that society must grapple with in the future of a multiracial United States. I, for the most part, have been accepted by both the Mexican-American and Anglo communities. At the same time, I am self-conscious about where I fit in, fully aware that academic politics touching upon issues of race is a treacherous minefield. I am reminded occasionally in no uncertain terms that I might well not be employed, or at least not at as good a law school, if not for my identification with my MexicanAmerican ancestry. Two stories illustrate this point.

After several years of practicing law, I applied for a law teaching job. The American Association of Law Schools provides a standardized form résumé that makes it easier for law schools to quickly screen large volumes of faculty candidates. Along with an assortment of biographical information, such as where you attended law school, whether you were a member of your school's law review, whether you clerked for a judge, and where you have been employed, the form asks you to classify your background. As I always had done as far back as I can recall, I classified myself as Chicano. Before doing so, I wondered whether I should continue this practice. In discussing the matter with my wife, she asked me if I had grown ashamed of my background. That not being the case, I self-identified, though I worried that I might be viewed as an impostor by law schools in search of a bona fide Latino.

In one of my first interviews for a teaching position, I stepped into a senior professor's office. After the ordinary pleasantries, the question came-a question never posed to me in private law practice, but apparently one on the minds of members of many faculty appointment

229. See MARTínez, supra note 43, at $98-99$ (describing mixed Anglo/Mexican-American assimilationist of this type).

230. See supra text accompanying notes 142-154 (discussing importance of sumame in perception of Latino identity). 
committees: "How did you get to be a Mexican?"231 That at least is how I translated the question. Though asked numerous times in my life, the question generally has been presented in a more round-about, diplomatic way.

Sentiments like these have not been limited to my initial hiring. Shortly after I had earned tenure at U.C. Davis, a friend on the faculty appointments committee at another law school, which according to one ranking is a "top 20" school, asked if I was interested in interviewing for a job. I later flew out to interview. The day, at least from my end of the table, went extraordinarily well. Indeed, I made a presentation to the faculty that may have been my best ever. Many complimented me and I felt positive about the experience. The next day began with breakfast with the Dean of the law school. We talked for a bit about the school before he moved to the important issues. The Dean bluntly told me that, although the school did not have any "regular" faculty positions open, the central administration might give the law school an additional slot for a "minority hire."232 This all was news to me. The Dean continued. "Before we can even think about offering you a job, we will have to check to see if you qualify as a minority." These few words quickly brought me down to earth. Maybe the previous day had not gone so well. Maybe they just wanted a Latino for political reasons. The school at the time was on the Hispanic National Bar Association's "Dirty Dozen" list of law schools, a select group of schools with no Latino faculty members.

$$
* * * *
$$

In important ways, my search for identity is the bellwether for the future. As increasing numbers of multiracial people in the United States mature, they will grapple with some of the issues with which $I$ have struggled. Mixed Latinos do not fit neatly in the Anglo community. At the same time, they may be viewed with suspicion by some Latinos. My experience has been that others await an explanation when I claim to be Mexican-American. This has been especially true in academic life with its unique racial politics.

231. Other Latinos have had similar experiences. See Derrick Bell \& Richard Delgado, Minority Law Professors' Lives: The Bell-Delgado Survey, 24 HARv. C.R.-C.L. L. REv. 349, 362 (1989) (describing similar incident in which light-skinned Hispanic with Spanish surname was asked at interview "why she had indicated on her form that she was a Hispanic"); Hernández Truyol, supra note 105, at 409-10 (relating story of interview of Latina for law teaching position questioned about her parents' professions and being told that Chicano students would be unable to relate to her).

232. See Richard Delgado, Rodrigo's Tenth Chronicle: Merit and Affirmative Action, 83 Geo. LJ. 1711, 1713-14 (1995) (telling fictional account of Rodrigo who learned after hiring that he had received a "special opportunity appointment" for minorities). 
Ultimately, persons of mixed backgrounds are left little space in the modern debate over race relations. With the increasing number of mixed-race Latinos, as well as mixed-race people generally, in the United States, one might expect more blurring of the physical differences traditionally relied upon to demarcate the so-called races. Who is White and who is not will become increasingly difficult to tell by physical appearance. How society will address these racial complexities is far from clear.

\section{ConCLUSION}

Immigration restrictionists, in advocating for closing the U.S. borders, often proclaim that today's immigrants, unlike those of generations past, refuse to assimilate. The underlying assumption is that immigrants of the modern era are identical to the White ethnic immigrants of the $1800 \mathrm{~s}$. As history teaches, however, immigrants of color often have had vastly different experiences than their White predecessors. Anglo society has often accused them of the crime of failing to assimilate. Indeed, the infamous Chinese exclusion laws of the $1800 \mathrm{~s}$ and the internment of persons of Japanese ancestry during World War II were rationalized, and upheld by the Supreme Court, on the ground that Chinese and Japanese persons had failed to assimilate. Similar charges have taken root against Latinos, Asian-Americans, and others in the modern immigration debate.

This Article has focused on the difficulties of assimilationencapsulated by the "ring of fire" metaphor-faced by persons of Mexican ancestry in the United States and Latinos generally. Because many differ from members of the dominant Anglo society in physical appearance and other salient differences, Mexican-Americans have faced serious impediments to assimilating into the mainstream. Political and economic assimilation are far from complete and Latinos frequently are treated as "strangers in the land."233 This is even true for Mexican-Americans like my mother who made every possible effort to assimilate-Anglicizing her name, claiming she was Spanish and denying her Mexican ancestry, and marrying Anglos. These efforts failed with tragic consequences.

While the problems and issues may be different, assimilation also can be difficult for persons of mixed Anglo/Latino backgrounds. Some identify as being Latino with the costs this might entail, while others

233. I borrow this phrase from John Higham, Strangers in the Land: Patterns of American Nativism, 1860-1925 (2d ed. 1992). 
attempt to bury their past and suffer in different ways. This volitional nature of Latino identity adds much to the argument that race is a social, as opposed to a biological, construction. Moreover, intermarriage, by increasing the number of mixed Latinos, has steadily increased the diversity of the extremely heterogeneous Latino community in the United States. Although attention has been paid to Latino diversity in recent years, little has been paid to this component of the community. It should not be ignored, however, that Anglo-Latinos live in their own "ring of fire." 
LA RAZA LAW JOURNAL

CALIFORNIA LAW REVIEW 